\title{
Quaternary geomorphological and climatic changes associated with the diversification of Iberian freshwater fishes: the case of the genus Cobitis (Cypriniformes, Cobitidae)
}

\author{
Andrea Corral ${ }^{1}$, Silvia Perea ${ }^{1}$, Anabel Perdices ${ }^{1}$, and Ignacio Doadrio ${ }^{1}$ \\ ${ }^{1}$ Museo Nacional de Ciencias Naturales
}

October 19, 2021

\begin{abstract}
We studied the population genetic structure of Cobitis vettonica, an endangered freshwater fish species endemic to the Iberian Peninsula in order to propose a biogeographic model of the responses of species to the multiple changes that occurred in the Iberian hydrological system during the Quaternary period. We also deciphered the relationship of C. vettonica with its sister species C. paludica, particularly in sympatric areas and provide genetic information for conservation purposes. To achieve this end, we analysed both mitochondrial and nuclear data (the cytochrome $\mathrm{b}$ and the nuclear recombination activating 1 genes) and a battery of single nucleotide polymorphisms (SNPs) of 248 individuals of C. vettonica or C. paludica from 38 localities, including some sympatric ones, covering the entire distribution area of C. vettonica. We highlight the important role played by the hydrogeomorphological processes and climatic changes that occurred in the Iberian Peninsula during the Quaternary on both the population structure of C. vettonica and its relationship with its sister species C. paludica. Our results support the genetic introgression of populations at the eastern limit of the distribution of C. vettonica. Furthermore, we postulate genetic introgression in sympatric areas. Finally, we propose the establishment or expansion of four OCUs for C. vettonica, and highlight the threat faced by its populations due to the low level of genetic diversity detected for some of its populations and genetic introgression with C. paludica, which could eventually displace C. vettonica, resulting in a loss of diversity in this species.
\end{abstract}

\section{Introduction}

The Quaternary is a geological period characterized by glacial-interglacial cycles that have dominated the global climate since 2.58 Mya to the present era (Pillans and Naish 2004; Gibbard et al. 2010), which have had drastic consequences on the evolution of the biota of many regions. Due to advances in the field of phylogeography, we have a better understanding of the responses of organisms to Pleistocene events (Hewitt 2004; Weiss and Ferrand 2007). Classical studies support the role of Mediterranean peninsulas as refuges for fauna during the Quaternary, which provided the stock for recolonizations of northern and central Europe (Taberlet and Bouvet 1994; Hewitt 1996). The Iberian Peninsula is considered one of the most important refuges during this period, as shown by several studies, mainly of terrestrial fauna (Valdiosera et al. 2008; Querejeta et al. 2017).

Primary freshwater fishes have limited dispersal abilities, and are often restricted to specific hydrographic basins. Dispersal between basins during the Quaternary was possible mainly through downstream connections caused by the decrease in sea level during cold periods or by upstream piracy (Mesquita et al. 2005; Perea and Doadrio 2015; Corral-Lou et al. 2019). The formation of the Iberian fluvial network also culminated during this period, which affected the region's hydrogeomorphology and therefore the current evolutionary patterns found in primary freshwater fauna (Alonso et al. 2007; Pais et al. 2012; Perea et al. 2016; Corral-Lou et al. 2021). Likewise, the current population structure of many Iberian freshwater fishes 
has been attributed to the interaction of various factors that occurred during the Quaternary (Gante et al. 2009; Casal-López et al. 2017).

Despite efforts made in the last several decades, there is still much to be learned about the impact of Quaternary changes on the evolutionary processes and patterns of diversification of Iberian freshwater fish populations, especially of those species with a restricted distribution range. In order to address some open evolutionary questions, we analysed populations of Cobitis vettonica as a case study. This species is an endangered Iberian freshwater fish whose distribution is restricted to a few rivers in the Tagus and Duero basins in the mid-western Iberian Peninsula (Figure 1). It inhabits rivers with low $\mathrm{pH}$ and water hardness levels, and gravel and rocky bottoms, and is more commonly found in the headwaters of these rivers (Carmona et al. 1999; Doadrio et al. 2011; Perdices and Coelho 2020; Collares-Pereira et al. 2021). By contrast, the sister species of C. vettonica, Cobitis paludica(Perdices and Doadrio 2001; Doadrio and Perdices 2005), is a generalist that inhabits most of the Iberian drainages including Tagus and Douro, with a preference for streams close to the main channel with high suspended solids, high water hardness, low transparency, low current velocity and muddy bottoms (Carmona et al. 1999; Doadrio et al. 2011). Sympatric zones of $C$. vettonica and C. paludica have been reported in the western limits of the distribution area of $C$. vettonica (Perdices and Coelho 2020), as has genetic introgression of some eastern populations (Doadrio et al. 2011; Doadrio et al. 2021). Sister species of Iberian freshwater fishes generally have an allopatric distribution that was established mainly before the Quaternary (Doadrio 1988; Sousa-Santos et al. 2019), with sympatry between sister species being a consequence of secondary contacts during the Quaternary, which has led to genetic introgression in some cases (Machordom et al. 1990; Denys et al. 2013; Perea et al. 2016; Corral-Lou et al. 2019). In the case of C. vettonica and C. paludica, phylogenetic studies have shown they diverged during the Plio-Pleistocene (Doadrio and Perdices 2005; Sousa-Santos et al. 2014). However, both the origin of the sympatric zones between $C$. vettonica and $C$. paludicaand the plausible genetic introgression between them in the western distribution area of $C$. vettonica are unknown. All of these points make C. vettonica a good model with which to study the influence of the various processes that occurred during the Quaternary on the phylogeographic and biogeographic patterns of a freshwater fish species with a restricted distribution range in an ancient European refugium.

Phylogeographic studies of Iberian primary freshwater fishes have mainly used mitochondrial genes combined with nuclear markers such as microsatellites or introns (González et al. 2014; Perea et al. 2015; Casal-Lopez et al. 2018; González et al. 2018; Corral-Lou et al. 2019). In recent years, phylogeographic and population genetics studies have taken advantage of next generation sequencing (NGS) technologies to broadly screen the genome at high resolution, yet some challenges remain in the analysis of NGS data (McCormack et al. 2013; Tan et al. 2019). To overcome the limitations of using a single type of marker, combined analyses of, for instance, single nucleotide polymorphisms (SNPs) with mitochondrial and nuclear markers have proven useful to provide more complete and detailed phylogeographic and biogeographic models of the past and present relationships of populations of various species (Zarraonaindia et al. 2012; Mendes et al. 2019; Corral-Lou et al. 2021).

The main aim of this study is to provide a robust biogeographic model for the species $C$. vettonica throughout its entire distribution as a witness of the evolution of the Iberian Peninsula throughout the Quaternary. We also decipher the relationship of $C$. vettonicawith its sister species $C$. paludica at the limits of its distribution area. In addition, we assess the population structure and genetic diversity of the species across its distribution to revise the Operational Conservation Units (OCUs; Doadrio et al. 1996) previously established for $C$. vettonica (Doadrio et al. 2021) or to establish new ones. More detailed and accurate OCUs and decipher the relationship with its sister species throughout its entire range are key for the effective management and conservation of the endangered $C$. vettonica . To achieve these ends, we analysed the mitochondrial markercytochrome $b$ (MT-CYB), the nuclear markerrecombination activating gene 1 (RAG1) and a set of SNPs obtained through next-generation sequencing of populations throughout the entire distribution range of $C$. vettonica and some of $C$. paludica from adjacent sub-basins.

\section{Materials and Methods}


Sampling, DNA extraction, amplification and sequencing

We sampled 204 individuals of $C$. vettonica and 60 of C. paludica from a total of 38 localities (Figure 1; Table 1). The 27 localities (23 in the Tagus and 4 in the Duero) in which C. vettonica was found cover the entire known distribution area of the species, and includes its type locality (Arrago River, Tagus Basin). The samples of $C$. paludica were collected from 13 localities, including its type locality (Tietar River, Tagus Basin): of these, 11 were either adjacent to those of $C$. vettonica or in sympatric localities in the Tagus Basin, and two were in the Duero Basin (Figure 1; Table 1). Tissue samples were obtained from the DNA and Tissue Collection at the National Museum of Natural Sciences of Madrid (MNCN-CSIC; Table S1). Sequences of $M T-C Y B$ of C. vettonica and C. paludica available in GenBank were also included in the study (33 of C. vettonica and 7 of C. paludica ; Table S1).

For each individual, DNA was extracted from ventral fin tissue using the Qiagen DNeasy(r) Blood and Tissue Kit (Qiagen, Inc., Valencia, CA, USA), following the manufacturer's protocol. Polymerase chain reaction (PCR) was used to amplify 1,140 bp of $M T-C Y B$ from 208 individuals (164 of C. vettonica and 44 of $C$. paludica), and 1,500 bp of RAG1 from 90 individuals (66 of $C$. vettonica and 24 of $C$. paludica) (Table S1). Amplifications were performed following the protocol described by Doadrio and Perdices (2005) for MT-CYB , and Corral-Lou et al. (2021) for RAG1 .

All sequences (the new ones and the ones downloaded from GenBank) for MT-CYB (248 sequences) and RAG1 (90 sequences) were aligned using MAFFT (Katoh and Standley 2013), as implemented in Geneious 10.1.3 (http://www.geneious.com; Kearse et al. 2012), and then manually examined. Alleles of $R A G 1$ were separated using the PHASE algorithm (Stephens and Donnelly 2001; Stephens et al. 2003), as implemented in DnaSP v. 6.10.01 (Rozas et al. 2017).

\section{Genotyping and SNP filtering}

For the SNP study, we selected eight populations of each C. vettonica and C. paludica (Table 1) based on the structure observed in a previous study using mitochondrial data and available DNA (Doadrio et al. 2021). A total of 106 individuals (60 of $C$. vettonica and 46 of $C$. paludica; Table S1) were used to prepare libraries for double digest restriction site-associated DNA sequencing (ddRAD-seq) following the protocol described by Kess et al. (2016). Some of the samples were sequenced in two lanes of an Illumina HiSeq 2500 PE100 sequencer in Rapid-Run mode. The rest of the samples were run later in a fraction of a NovaSeq 6000 PE150 lane. Trimmomatic 0.36 (Bolger et al. 2014) was used to remove adapters (ILLUMINACLIP option). Using the process_radtags program in STACKS 2.4 (Catchen et al. 2013), all reads were truncated to the same length of $95 \mathrm{bp}$, and low quality reads were removed using the -q parameter. A de novo_map analysis was also performed in STACKS, in which different programs were run to assemble loci in each individual (ustacks ), build a catalogue (cstacks), match all generic samples against the catalogue (sstacks) and reconstruct loci using R2 reads and identify SNPs using the metapopulation information (gstacks ). Prior to running the STACKS modules, several tests were used to identify which parameters maximized the number of SNPs obtained in at least $80 \%$ of the individuals (r80 rule; Paris et al. 2017), which were $m=5, M=3$ and $n=4$. The program populations, also in STACKS, was used to filter the SNPs using the following parameters: -R $0.80,-$ min_maf $=0.05,-$ max_obs_het $=0.75$ and - write_random_snp.

Two matrices for the SNPs were built. The first included the populations of $C$. vettonica and data from 60 individuals from eight localities and 4,000 polymorphic loci. The second included populations of both $C$. vettonica and C. paludica, referred to as C. vettonica + C. paludica, and data from 106 individuals from 16 localities and 4,538 polymorphic loci.

Phylogeny

A phylogenetic tree was constructed to assess relationships based on the collapsed $M T-C Y B$ haplotypes matrix. The selected substitution models were SYM, HKY $+\mathrm{I}$ and GTR $+\mathrm{G}$ for the first, second and third position, respectively, based on the results obtained in PartitionFinder2 (Lanfear et al. 2017) using the Akaike information criterion (AIC; Akaike 1974). The analysis was implemented in MrBayes v3.2 (Ronquist et al. 
2012), with two simultaneous independent runs each with four Markov chain Monte Carlo (MCMC), which were run for $5 \times 10^{7}$ generations. The first $25 \%$ of generations were removed as burn-in. Posterior probability (pp) values were used to assess the reliability of the phylogenetic hypothesis. Two sequences of other species of Cobitis were used as outgroups: C. bilineata (EF605321.1) and C. zanandreai (AF263089.1). The genetic divergence between the lineages obtained in the $M T$-CYBanalysis was evaluated through uncorrected $p$ distances with 1,000 permutations using MEGA v.6.0 (Tamura et al. 2013). For the SNP data, phylogenetic relationships were evaluated using the complete SNP matrix $(C$. vettonica $+C$. paludica $)$ through the Maximum Likelihood (ML) method in the RaxML program implemented in CIPRES Science Gateway v3.3. The evolutionary model selected was ASC_GTRGAMMA, as recommended in the program manual for data that contain only variable sites, and the Lewis ascertainment bias correction was used (Stamatakis 2016). The robustness of the tree was evaluated with 1,000 bootstrap (b) replicates.

\section{Genetic structure}

To examine the genetic structure of all studied populations of C. vettonica and C. paludica, haplotype networks for the two genes were constructed using the median-joining algorithm (Bandelt et al. 1999) implemented in PopART (Leigh and Bryant 2015). Analysis of molecular variance (AMOVA) was used to determine the source of the genetic variation in $M T-C Y B$ for the populations identified as C. vettonica using different groupings based on basin, sub-basin and evolutionary lineage. These analyses were implemented in Arlequin v.3.11 (Excoffier and Lischer 2010) with 10,000 permutations. Population differentiation in terms of $\Phi$ st (Hudson et al. 1992) between all population pairs (except those represented by only one individual) for the complete dataset (C. vettonica and C. paludica) was also calculated in Arlequin v.3.11. For the localities in which mitochondrial haplotypes of both $C$. vettonica and $C$. paludica were found, the $\Phi$ st was calculated by treating the individuals of each species as separate populations.

STRUCTURE (Pritchard et al. 2000) was used to assess the genetic structure based on the two SNP matrices. The most probable number of subpopulations $(\mathrm{K})$ for each analysis was equal to the number of populations studied +1 ( $\mathrm{K}=9$ and $\mathrm{K}=17$, respectively). We performed 10 independent simulations for each $\mathrm{K}$ with a burn-in length of 50,000 and 50,000 MCMC repetitions after the burn-in. The most probable number of subpopulations for each matrix was estimated by taking into account the results of both the $\Delta \mathrm{K}$ (Evanno et al. 2005) and the Puechmaille method (Puechmaille et al. 2016). The web server StructureSelector (Li and Llu 2018) was used to make these estimations. We selected K based on both methods because a greater probability of $\mathrm{K}=2$ exists when the structure is analyzed with the $\Delta \mathrm{K}$ method (Janes et al. 2017), and similar results for different methods indicate a clear signal (Puechmaille et al. 2016).

Genetic diversity and demography

Different genetic diversity parameters were estimated for bothMT-CYB and RAG1 in DnaSP for each river, sub-basin, species and evolutionary lineage. For $M T-C Y B$, the populations with shared haplotypes between C. vettonica and C. paludica were analysed considering only the individuals identified as C. vettonica. The parameters were calculated for the following groups: river, sub-basin, species and evolutionary lineage. For the SNP data, a different set of genetic diversity parameters was estimated using the populations program in STACKS 2.4 (Catchen et al. 2013). These parameters were evaluated for the two matrices independently $(C$. vettonica and $C$. vettonica + C. paludica), however, only the results for $C$. vettonica are shown. In addition, a third matrix was studied taking into account the populations of both species, except the populations of the Aurela and Salor rivers of $C$. paludica, due to the close relationship that these localities showed with the localities of the Erjas sub-basin of $C$. vettonica .

To evaluate the demography of populations of $C$. vettonica, deviations from a model of mutation-drift equilibrium were tested using Fu's Fs (Fu 1997) and Tajima's D (Tajima 1989), as implemented in Arlequin v.3.11.

Divergence times and niche modelling

Divergence times among the populations of $C$. vettonica were estimated using a relaxed lognormal clock and 
a coalescent model on the collapsed MT-CYB haplotypes matrix in BEAST v 1.8.4 (Drummond et al. 2012). The molecular clock was calibrated using, as a normal prior, an evolutionary rate of $0.34 \%$ divergence per lineage per million years (Doadrio and Perdices 2005), and the substitution model used was GTR+I.

To identify the potential niche of $C$. vettonica in both past and present scenarios, ecological niche models, as applied in the software MaxEnt v.3.4.1 (Phillips et al. 2017), were used to predict a mean habitat suitability value for each locality. To select the most appropriate of the 19 accessible bioclimatic variables (Fick and Hijmans 2017) for the final analysis, correlation and collinearity analyses and preliminary analyses were first performed. Three variables based on the ecological characteristics of the species were chosen for the final analysis: Isothermality (BIO3), Precipitation of Driest Month (BIO14) and Precipitation Seasonality (BIO15). The data matrix on the presence of the species included only the studied populations of $C$. vettonica that do not have any putative genetic introgression with C. paludica. The niche modelling was made for three periods of time: Present (the years 1970 to 2000), Last Glacial Maximum (LGM; 22,000 years before present, BP) and Last Interglacial (LIG; ${ }^{120,000-140,000 ~ B P) . ~ T h e ~ q u a l i t y ~ o f ~ t h e ~ m o d e l ~ w a s ~ e v a l u a t e d ~ b y ~}$ the Area Under the Curve (AUC) derived from the Receiver Operating Characteristic (ROC).

Ancestral area reconstructions

The ancestral areas of $C$. vettonica were reconstructed using both the S-DIVA (Yu 2010) and S-DEC (Ree and Smith 2008; Beaulieu et al. 2013) methods implemented in RASP v.4.2 (Yu et al. 2015; Yu et al. 2020). The established areas were based on the current hydrographic subdivision of the Iberian Peninsula. Due to the genetic differentiation detected for $M T-C Y B$ in the Alagón sub-basin, this area was divided into an eastern and a western part. The code for the areas was as follows: A: Águeda, B: Western Alagón, C: Eastern Alagón, D: Aravil, E: Erjas, F: Ponsul, G: Salor, H: Ocreza, I: Aurela, J: Huebra and Yeltes, K: Tamuja and Almonte, L: Ibor and M: Tiétar. We used the BEAST-derived trees as the input files for RASP. We eliminated $50 \%$ of the total initial trees, and used 100 random trees for the analysis. Ancestral ranges were limited to include no more than three adjacent areas. Only the reconstructed areas for $C$. vettonica are shown as this lineage is the focus of the present study.

\section{Results}

Phylogeny

The phylogenetic analysis of $M T-C Y B$ recovered two main lineages corresponding to the species $C$. vettonica (S1) and C. paludica (S2) with high support ( $\mathrm{pp}=1$; Figure $\mathrm{S} 2$ ). The species C. vettonica (S1) was not monophyletic since many individuals identified morphologically as $C$. vettonica from the Alagón sub-basin populations were found in both lineages (i.e. Jerte, Francia, Alagón, Caparro, Cuerpo de Hombre [Cdh] and Gata rivers). The lineage of $C$. paludica (S2) was also not a monophyletic group since one individual identified morphologically as C. paludica from the Salor sub-basin was included in the C. vettonica lineage (S1). Within C. vettonica (S1), there were two well differentiated lineages (Figure S2). The first grouped populations from the Alagón sub-basin in the Tagus Basin and those from the Águeda sub-basin in the Duero Basin. Within this lineage, these populations grouped into two distinct lineages, V1 and V2. The populations from the eastern Alagón sub-basin formed the V2 lineage $(\mathrm{pp}=0.99)$, while those from the western Alagón and Águeda sub-basins, and one individual from Jerte River that was not included in V2, formed the V1 lineage. The phylogenetic relationships of the sequences included in V1 were not resolved. However, within $\mathrm{V} 2$, we detected another highly supported monophyletic grouping $(\mathrm{pp}=1)$ in which only the single individual studied from Ladrillar River was excluded. The second well differentiated lineage within C. vettonica (V3; $\mathrm{pp}=1$ ) included populations from the Ponsul, Aravil and Erjas sub-basins located along the western limit of the species' distribution range, and one individual from Salor River (Figure S2).

Genetic distances among the three lineages detected in C. vettonica (V1, V2 and V3) ranged from $0.3 \%$ to $1.2 \%$ (Table S2).

The unrooted phylogenetic tree of $C$. vettonica and $C$. paludica based on the 4,538 SNPs was largely congruent with the results obtained in the phylogenetic reconstruction for $M T-C Y B$, although with some slight 
differences (Figure 3). The individuals of the populations analysed for SNPs belonging to the V1 lineage (i.e. Mayas from Águeda sub-basin, Duero Basin and Gata from western Alagón sub-basin, Tagus Basin) were well differentiated not only from the rest of the individuals analysed ( $>>90)$ but also from each other $(b>90$ and $75<\mathrm{b}>90$, respectively). Those belonging to the V3 lineage (Erjas River), which were separated from the rest of the populations of $C$. vettonica, were more related to individuals of $C$. paludica from Aurela River, a tributary of the Tagus Basin that is geographically close to the Erjas sub-basin. Likewise, individuals of C. vettonica from the Caparro river population (belonging to V2 and S2) were more related to those of $C$. paludica from the populations in the Salor, Tamuja, Ibor, Huebra and Yeltes rivers. The remaining populations of C. vettonica included in the SNP analysis belonging to the V2 and S2 lineages (Alagón, Cdh, Jerte and Francia rivers) did not show a clear phylogenetic structure with several intermediate individuals.

\section{Genetic structure}

The haplotype network for $M T-C Y B$ was consistent with the phylogenetic reconstruction for $M T-C Y B$. The network showed two main groups separated by 20 mutational steps corresponding to the species $C$. vettonica and C. paludica (S1 and S2, respectively; Figure 4). For C. vettonica (S1), the network was more informative than the phylogenetic reconstruction since there were three well differentiated haplogroups (V1, V2 and V3). The first haplogroup (V1) clustered populations from the Águeda sub-basin in the Duero Basin and in the Tagus Basin, those from the western part of Alagón sub-basin, plus one individual belonging to Jerte River (eastern Alagón sub-basin) (Figure 4). These populations corresponded to the non-differentiated lineage obtained in the phylogenetic reconstruction (i.e. V1 in Figure 2). The second haplogroup (V2) was composed of all the eastern Alagón sub-basin populations in the Tagus Basin, corresponding to the V2 lineage obtained in the phylogenetic reconstruction. Likewise, the third haplogroup (V3), corresponding to the V3 lineage in the phylogenetic reconstruction, included populations from the western limit of the distribution range of C. vettonicain the Tagus Basin, namely those from the Ponsul, Aravil and Erjas sub-basins, plus one individual from Salor River. The individual from Salor River (identified as C. paludica) presented the most common haplotype of the haplogroup. Haplogroups V1 and V2 were separated by three/four mutational steps, and V3 was separated from V1 by 10 mutational steps. In the group comprising haplotypes found mainly in C. paludica (S2), a subset was composed of individuals identified as C. vettonica from the Alagón and Erjas sub-basins (V4; referring to only those individuals identified morphologically as C. vettonica but that are genetically closer to C. paludica according to the mitochondrial data) along with other individuals of $C$. paludica from other Tagus and Duero tributaries. However, no evidence of a geographic structure was found within S2. The haplotype network for the nuclear marker ( $R A G 1$ ) showed a single group in which all studied populations of both species were represented and therefore was of low resolution (Figure S1).

According to the AMOVAs with the $M T-C Y B$ data, the highest percentage of variance among groups was when the groupings were comprised of the lineages found in the previous analysis (V1, V2, V3 and V4; Table S4). The percentage of variance explained between basins (Duero and Tagus) was not significant, with most of the variation explained by differences between and within populations. Population differentiation between localities within each lineage of $C$. vettonica for $M T-C Y B$ was low $(\Phi \sigma \tau<0.34)$, and no significant differences were found, except for the Acebo River, which showed a high level of differentiation with the Árrago river $(\Phi \sigma \tau>0.74$; Table S5). High values of $\Phi \sigma \tau$ were detected between populations from different haplogroups $(\Phi \sigma \tau>0.75)$.

The results of the SNP structure analyses showed that the most probable number of subpopulations (genetic groups) was $\mathrm{K}=4$, when both methods and all localities of $C$. vettonica were taken into account (Table S6). For $\mathrm{K}=4$, only three populations showed very little admixture: Mayas River in the Duero Basin (first group, in yellow) and Caparro and Erjas rivers in the Tagus Basin (second and third groups, in blue and purple, respectively) (Figure 5). The other populations (Alagón, Cdh, Jerte and Francia) showed different degrees of admixture of the second (blue) and fourth (orange) groups. Gata River had a similar level of admixture of the first (yellow) and fourth (orange) groups with a small contribution from the third (purple). When we analysed the populations of both species, the most probable number of subpopulations was $\mathrm{K}=6$ (Table $\mathrm{S} 6$ ). For $\mathrm{K}=6$, Mayas and Gata comprised the first group (orange), with Gata having a small contribution 
from the third group (purple) in all individuals (Figure 5). Alagón, Cdh, Jerte, Francia and Caparro showed different degrees of admixture of the first (orange) and second (blue) groups, with Cdh and Francia also having a small proportion of the third group (purple) and Jerte having a small proportion of the fourth group (light pink). The second group (blue) was present in all populations of C. paludica. The upper Erjas River was assigned to a single genetic group (Group 3; purple), which also comprised approximately $29 \%$ and $15 \%$ of the total composition of the Aurela and Salor rivers, respectively, with very small contributions from the second (blue) and fifth (pink) groups in some individuals.

Genetic diversity and demography

Overall genetic diversity parameters for all individuals identified as $C$. vettonica based on $M T-C Y B$ were high (Table 2). Excluding populations of $C$. vettonica in which only one individual was studied, $H d$ ranged from 0 to 1 , and $h$ ranged from 1 to 7 . The populations with the lowest values of genetic diversity were Mayas, Acebo, Arades and Caparro with only one haplotype each (Table 2). The most variable populations for all of the diversity parameters were the lower and middle Erjas, Alagón and Gata. The sub-basins with the highest genetic diversity values were Erjas and Alagón, specifically the western Alagón sub-basin. The one with the lowest values was Águeda with only one haplotype.

The highest number of private alleles for C. vettonica, based on the SNP data, was found in the upper Erjas (227 alleles) and Caparro (76 alleles) rivers (Table S3). However, when the complete matrix including the populations of $C$. paludica was taken into account, the number of private alleles decreased drastically for all rivers, except Mayas (41 vs 40) and Gata (1 vs 0), whose numbers remained nearly the same as when only C. vettonica was considered. In the upper Erjas and Caparro rivers, the number of private alleles decreased to eight and two, respectively (Table S3). Notably, when Aurela and Salor rivers were removed from the analysis, the number of private alleles in the Erjas population rose to 141. The lowest nucleotide diversity values were found in Mayas, Gata and the upper Erjas rivers, and the highest, in Alagón, Cdh, Jerte, Francia and Caparo rivers (Table S3).

Significant negative values for the neutrality tests indicate a population expansion following a bottleneck. All three of the detected lineages were significantly negative for Fu's FS; V2 and V3 were also significantly negative for Tajima's D.

Divergence time and niche modelling

The topology of the tree obtained by calibrating the molecular clock (Figure S2) was identical to that of the phylogenetic Bayesian tree (see Figure 2) but showed higher support for the V2 lineage ( $\mathrm{pp}=0.99$ vs $\mathrm{pp}=0.87$ ). The V3 lineage diverged approximately $250 \mathrm{Ka}(\mathrm{HPD} 95 \%: 30 \mathrm{Ka}-2.76 \mathrm{Ma}$ ), while V1 and V2 diverged from each other approximately 80,000 years ago (HPD 95\%: $10 \mathrm{Ka}-910 \mathrm{Ka}$ ).

All niche distribution models (Figure 6) had AUC values greater than 0.97. Values above 0.75 are considered useful, while those above 0.90 are very good (Swets 1988; Elith et al. 2006). Mean habitat suitability values above 0.7 were found for the present-day period for all localities where C. vettonica is currently present, except some areas of the eastern Alagon sub-basin, including Jerte, Francia, Caparro, Alagon and Cdh rivers, and the lower and middle courses of the Ponsul and Aravil sub-basins. In addition, a potentially habitable zone outside the known current distribution area for C. vettonica was observed upstream of Aurela River, a tributary of the left margin of the Tagus Basin, and also upstream of Coa River, a tributary of the Duero Basin that is adjacent to the Agueda sub-basin (Figure 6A,B). For the LIG period (Figure 6C), the area with the optimal conditions for the species generally overlapped with that found for the present, although the highest probability values were concentrated in the central part of the species' current distribution (i.e. the western Alagon and Agueda sub-basins in the Tagus and Duero basins, respectively). For the LGM period (Figure 6D), optimal conditions were located in the southwestern area of the species current distribution (the Erjas and lower Arrago sub-basins and Salor, Aravil and Ponsul sub-basins). Some rivers outside the current distribution of the species in Portugal also showed optimal conditions.

Ancestral area reconstructions 
In general, the results of the ancestral area reconstructions using either the S-DIVA or S-DEC method were congruent (Figure S3). Both the vicariant events between lineages and the ancestral area with the highest marginal probability were consistent between the two methods. The most probable ancestral areas were as follows: Alagon-Erjas sub-basins for the junction node of V1-V2-V3, Alagon sub-basin for V1-V2 and Erjas sub-basin for V3. Both analyses supported the diversification of the main evolutionary lineages due to vicariant events. Several dispersal and vicariant events were also detected within V1 and V3 (Figure S3).

\section{Discussion}

\section{Genetic structure}

A strong population genetic structure, based on mitochondrial (MT-CYB) and SNP data, was detected for C. vettonica, in line with previous molecular studies of $M T-C Y B$ (Perdices and Coelho 2020; Doadrio et al. 2021). No differences were found for nuclearRAG1, neither among the populations of $C$. vettonica nor between $C$. vettonica and C. paludica. Similar findings have also been reported for this gene in other Iberian species, probably as a consequence of incomplete lineage sorting (Corral-Lou et al. 2019; Perea et al. 2021).

The population structure of $C$. vettonica based on the mitochondrial data differed from the main pattern observed in other European freshwater fishes, which is that gene flow within the same basin is greater than among different basins (e.g. Seifertova et al. 2012; Buj et al. 2017; Marić et al. 2017; Corral-Lou et al. 2019; Marić et al. 2019; Wetjen et al. 2020). Specifically, for C. vettonica, genetic differentiation between populations from the same basin (Tagus Basin) is greater than between populations from the two main basins (Duero and Tagus basins). Similarly, greater differentiation within the same sub-basins than between different sub-basins has been found forAchondrostoma salmantinum, which has a restricted distribution area that partially overlaps with that of $C$. vettonica(Corral-Lou et al. 2021). Iberian freshwater fishes with a wider distribution range that partially or completely overlaps with that of $C$. vettonica, such as Squalius carolitertii , S. pyrenaicus, S. alburnoides or Luciobarbus bocagei, do not show a population structure pattern similar to that of $C$. vettonica (Doadrio et al. 2002; Cunha et al. 2004; Sousa-Santos et al. 2007; Perea et al. 2021). Differences in the genetic pattern of the various species may be due to differences in size and dispersal abilities: Cobitis are small benthic organisms with lower dispersal abilities (like A. salmantinum ) compared with those ofLuciobarbus and Squalius, which are larger and have higher dispersal abilities (Doadrio et al. 2011). This difference in the biology of freshwater fish species, along with different colonization times, could account for the population structure found in C. vettonica and A. salmantinum and the lack of structure in species of Luciobarbus and Squalius (see Biogeography section).

\section{(V1) Western Alagón Sub-basin and Duero Basin}

This mitochondrial lineage included the populations from the headwaters of the rivers in the western Alagón sub-basin in the Tagus Basin, and those in the Duero Basin. Only one individual from Jerte River in the eastern Alagón sub-basin had a haplotype close to the western lineage, however, it was not shared by any other locality in the western Alagón sub-basin or the Duero Basin. Therefore, it is possible that the close relationship between this and the rest of the haplotypes is a consequence of an ancestral polymorphism; hence, we did not consider Jerte River within this lineage. The results of the SNP analyses showed slight differentiation between the Duero and Tagus populations, indicating that these isolated populations were joined in the past. These results suggest that the Duero basin and western Alagón sub-basin populations of C. vettonica, which are currently assigned to single OCU (Doadrio et al. 2021), should be assigned to two separate OCUs (OCU I and OCU II, respectively; Figure 7).

The Duero populations of $C$. vettonica (OCU I) showed the lowest diversity values of all the populations. Two possible explanations may account for this low diversity: in the first case, these populations may have not yet recovered from a recent bottleneck that occurred following their separation from the western Alagón sub-basin, and in the second, they may have not yet diversified following a founder event that occurred after the estimated dispersal of a small number of individuals from the rivers of the western Alagón sub-basin (as suggested in our ancestral area reconstructions). 


\section{(V2) Eastern Alagón Sub-basin}

This group, composed of the populations from the eastern Alagón sub-basin, was not monophyletic based on $M T-C Y B$, and in the SNP analysis, presented a high level of admixture with $C$. paludica. These results suggest extensive genetic introgression of $C$. vettonica with its sister species $C$. paludica, except in Hurdano and Ladrillar rivers, where only one individual from each was studied. Therefore, regardless of the different levels of genetic introgression, we propose that these populations all be assigned to the OCU that was recently established by Doadrio et al. (2021) (OCU III; Figure 7).

\section{(V3) Ponsul, Aravil and Erjas sub-basins}

According to the MT-CYB analyses, the Ponsul, Aravil and Erjas sub-basin populations constituted a welldifferentiated independent lineage of $C$. vettonica, supporting evidence from other studies that suggest the uniqueness of the Erjas populations (Doadrio et al. 2011; Doadrio et al. 2021). The upper Erjas was also an independent group, according to the SNP analyses, indicating its present-day isolation with respect to the rest of the populations in the Alagón sub-basin and Duero Basin. For these reasons, we include the upper Erjas, Ponsul and Aravil sub-basins in the OCU previously established for only the Erjas sub-basin (Doadrio et al. 2021), thereby expanding this OCU's area of coverage (OCU IV; Figure 7).

Hybridization

Hybridization due to introgression as a result of both anthropic and natural factors has been detected for other Mediterranean cyprinid and cobitid species (Bohlen and Rab 2001; Cunha et al. 2004; Janko et al. 2005; Almodóvar et al. 2012; Denys et al. 2013; Tancioni et al. 2013; Choleva et al. 2014; Perea et al. 2016; Corral-Lou et al. 2019). Within the Iberian Peninsula, the majority of the natural hybrid populations originated during the Quaternary period as a consequence of hydrographical rearrangements and/or Pleistocene glaciation-deglaciation cycles (Gante 2009; Almodóvar et al. 2012). Consistent with this, we present strong evidence confirming the introgression previously reported in the eastern Alagón populations of $C$. vettonica by Doadrio et al. (2011, 2021), and also postulate the genetic introgression of populations in sympatric areas (Ponsul, Aravil and low Erjas; see below). Supporting this hypothesis is the location of these populations outside the potential range of the species based on the ecological niche models. The introgression of even a few loci due to hybridization can lead to adaptive divergence if the loci are better adapted to other niches and persist in the genome (Abbot et al. 2013).

\section{(V1) Western Alagón Sub-basin and Duero Basin}

The Gata population within the western Alagón sub-basin was the only one that presented a mitochondrial haplotype of C. paludica . However, in the SNP analysis, none of the individuals showed admixture with $C$. paludica, and they also resolved as a phylogenetically isolated group. Therefore, at present, there is no evidence to support genetic introgression with $C$. paludica in this area.

\section{(V2) Eastern Alagón Sub-basin}

We found strong evidence of genetic introgression between C. paludica and C. vettonica in the eastern Alagón sub-basin, in line with previous studies (Doadrio et al. 2011; 2021). These populations not only showed a high level of admixture with C. paludica but also high values of genetic diversity in the SNP analyses. Indeed, they had the highest values of all the populations, as would be expected for hybrids populations. The high diversity values obtained for the SNP data were not congruent with the low ones obtained for $M T-C Y B$. However, this observation is not surprising as hybrids typically cannot be detected by mitochondrial markers due to their maternal inheritance.

The case of the population from Caparro River is particularly interesting. It was the only eastern Alagon sub-basin population that showed a closer phylogenetic relationship with populations of $C$. paludica than with those of $C$. vettonica and a higher degree of genetic introgression. This fact could be explained by two hypotheses. The first is that the source population was $C$. paludica and, through a founder effect, a few individuals of $C$. vettonicaestablished themselves in this locality, giving rise to a population of $C$. paludica 
introgressed by $C$. vettonica. The second hypothesis is that the source population was $C$. vettonica, but it was displaced by C. paludica after this species' arrival due to its better adapted genome (Abbot et al. 2013).

\section{(V3) Ponsul, Aravil and Erjas sub-basins}

According to the mitochondrial analyses, the Ponsul, Aravil and Erjas sub-basin populations of C. vettonica were related to a population of $C$. paludica from Salor River whose most common haplotype was also shared by all of these populations of $C$. vettonica. In addition, the results of the SNP analysis revealed a strong relationship between the Erjas population (upper Erjas) with those in the Salor and Aurela sub-basins, particularly the latter with which it was most closely related phylogenetically. The relationship between these populations was more evident when the Aurela and Salor populations were removed from the SNP genetic diversity analysis, which resulted in an increase in the number of private alleles from eight to 141. However, in the SNP structure analysis, only one individual belonging to the Erjas population had a very low contribution of the genetic group assigned to C. paludica. Altogether, the results do not support the presence of genetic introgression in the upper Erjas, where no mitochondrial haplotypes of C. paludica were found. Moreover, higher values of genetic diversity would be expected for the SNP data if there were introgressions, as occurs in the eastern Alagon sub-basin populations; however, low values were observed in this case.

However, we postulate genetic introgression in the Ponsul, Aravil and lower Erjas sub-basin, where both species are present (Perdices and Coelho 2020). This postulation is based on their location outside the area indicated by the ecological niche models and the fact that introgression by hybridization is a common phenomenon that has been detected for not only $C$. vettonica and $C$. paludica but also other species of European Cobitis (Rab and Slavik 1996; Bohlen and Rab 2001; Janko et al. 2007). Furthermore, this general pattern has often been observed in the Iberian Peninsula for two sympatric species as a consequence of secondary contact after diversification (Perea et al. 2016; Corral-Lou et al. 2019; Doadrio et al. 2021; Perea et al. 2021).

Within this group, hybrid localities seem to be restricted to the lower reaches of rivers, while the upper reaches are inhabited by only C. vettonica (Perdices and Coelho 2020). The habitat preferences of the two species, C. paludica in the middle and lower reaches, and C. vettonica in the upper reaches (Doadrio et al. 2011), likely explains the restricted distribution of the hybrids.

\section{Biogeography}

According to our divergence time estimations, the timing of these divergences agrees with a common period of population differentiation for many Iberian freshwater fish species, which in turn coincides with the culmination of the formation of the Iberian drainage network and the Pleistocene glacial cycles (Pais et al. 2012; Perea et al. 2016; Casal-Lopez et al. 2017; Corral-Lou et al. 2019; Corral-Lou et al. 2021). Although geological information for the study area is scarce, several tectonic and climatic events are known to have occurred during the Quaternary, which could have influenced the hydrogeomorphology of the aquatic network and therefore the evolution of the populations of C. vettonica (Benito et al. 2003; Carrasco et al. 2013; Carrasco et al. 2015; Goy et al. 2020). Therefore, we propose several hypotheses based on the biogeography of the species, which may inform on the hydrogeomorphological evolution of the Iberian Peninsula.

The earliest divergence in C. vettonica was the Ponsul-Aravil-Erjas lineage (V3), which split from the two Alagon sub-basin lineages (V1-V2) during the Pleistocene (Calabrian period, $\sim 250,000$ Mya). Based on the ancestral area reconstructions, the diversification of these lineages occurred in the area currently comprising both the Erjas and Alagon sub-basins. This implies that the Erjas acquired its current configuration during this period of time, interrupting any gene flow that may have been established by connections between tributaries on the right bank of Erjas River and the left bank of Arrago River. Subsequently, following the isolation and diversification of the Erjas sub-basin population from the rest of the populations, individuals from this sub-basin dispersed to downstream areas of the Tagus Basin (reaching Ponsul, Aravil and Salor sub-basins). These dispersal events could have taken place as a consequence of climatic changes associated with the LGM, as supported by our niche models which indicated the Ocreza, Nisa, Sever, Ponsul, Aravil 
and Salor sub-basins as more suitable habitats than the rest of the rivers in the current distribution range of the species. These events gave rise to both the colonization of new areas to the west (Ponsul and Aravil sub-basins) and the sympatry with C. paludica, which led to introgression events.

The divergence of the two other lineages comprising the western and the eastern Alagon sub-basin populations (V1 and V2) also occurred during the Pleistocene (Chibanian period, 80,000 Mya). The complex geology of the Alagon sub-basin is evident by the anomalous current trajectory of some of its rivers (Carrasco and Pedraza 1991; Jimenez 1994; Schnabel and Gutierrez 2014; Diez Herrero 2018; Goy et al. 2020). For instance, the two banks of the Alagon sub-basin, represented by the two mitochondrial lineages, are currently joined by the mouth of the Arrago River in the Alagon River, that is, the main river of the western and the eastern Alagon sub-basin, respectively. The union between the two banks occurred relatively recently as a consequence of the upriver action of the Alagon River, which captured the Caparro River that eventually flowed into the Tagus through the Fresnedosa riverbank (Schnabel and Gutierrez 2014). Given this context, we propose two scenarios for the divergence of V1 and V2. In the first, the two lineages diverged prior to the union of the two banks and later genetic flow between populations was not possible due to the poor habitat conditions for $C$. vettonica in the lower Alagon sub-basin. In the second, they diverged after the union of the banks due to climatic changes during the LGM. According to our niche models, the optimal ecological conditions for $C$. vettonica were located further downstream and, as predicted by phylogeography theory, the latitudinal distribution of organisms retracted southwards (Hewitt 1996; Ehrich et al. 2007; Rodriguez et al. 2011). Once optimal conditions returned to the river headwaters, the species went back upstream towards both the east and west margins of the Alagon sub-basin, and subsequently diversified.

After the divergence of the two banks of the Alagon, the populations in the Duero and western Alagon subbasin diverged. Several studies have reported on the genetic structure of freshwater fauna associated with connections between the Tagus Basin and adjacent basins (e.g. Alagon, Alberche and Lozoya rivers; PerezGonzalez 1980; Doadrio 1988; Carmona et al. 2000; Sousa-Santos et al. 2007; Casas-Sainz and De Vicente 2009). Although recent connections may be explained as a consequence of the active tectonic activity in the region (Gay et al. 2020), there are no geological studies that support a recent connection between the western Alagon sub-basin (Tagus Basin) and the Agueda sub-basin (Duero Basin), despite the close proximity of some of their river headwaters (in some cases, as little as $150 \mathrm{~m}$ of linear distance). A connection, however, has been hypothesized to explain the co-occurrence of individuals with the mitochondrial genome of Squalius carolitertii (distributed in the Duero Basin) and those of S. pyrenaicus (distributed in the Tagus Basin) in the Arrago River (Perea et al. 2021). The close proximity of Mayas (Duero Basin) and Arrago (Tagus Basin) rivers, whose courses are only separated by $\sim 150$ meters, is particularly notable. Piracy events that occurred between these two rivers in the Pleistocene may explain the close mitochondrial relationship of the populations inhabiting them, as suggested by the dispersal event estimated in our ancestral area reconstruction analysis. Later isolation of the Duero and Tagus hydrological basins then led to the divergence of these populations, as corroborated by the SNP analysis.

\section{Conservation}

The habitats of $C$. vettonica have been and continue to be threatened by the main causes of biodiversity loss (e.g. overexploitation, water pollution, flow modification, habitat destruction and degradation and the introduction of invasive species) (Dudgeon et al. 2019; Doadrio et al. 2011; Sousa-Santos et al. 2014). Given these threats, the populations in OCU I (Agueda sub-basin) are particularly vulnerable as they had the lowest genetic diversity values for both $M T-C Y B$ and the SNPs, and only one $M T-C Y B$ haplotype shared by all the populations. This low level of genetic diversity makes them more sensitive to extrinsic changes and therefore at greater risk of extinction (Frankham et al. 2002). In addition, populations in OCU I are shrinking as a result of the formation of dams along the Agueda sub-basin, and in some localities (i.e. Turones), they have even disappeared. The species' distribution in this area is now restricted to a few tributaries of Mayas River. Although the genetic diversity values of populations in OCU II were higher than those of OCU I, the possibility of a bottleneck followed by a population expansion cannot be rejected for these populations, despite a decrease in the number of individuals observed in recent years (Doadrio et al. 
2011). Exotic species, such as Lepomis gibbosus and Micropterus salmoides, have colonized the upper parts of the rivers covered by OCU II, which may be one of the main causes for the decline in the number of $C$. vettonica in these rivers. Other potential causes of this decline remain unknown.

For OCU IV, there was no genetic distinction between the non-introgressed (upper Erjas) and putatively introgressed (Ponsul, Aravil and lower Erjas) populations. Despite this, any management plan must take into consideration this potential introgression as the indiscriminate mixing of individuals from these two groups could lead to genetic introgression with $C$. paludica throughout the entire area of OCU IV. Cobitis paludica, which is more of a generalist thanC. vettonica, is widely distributed throughout the Iberian Peninsula, occupying a great variety of ecological niches (Doadrio et al. 2011). Thus, genetic introgression by $C$. paludica in sympatric localities would likely prove disadvantageous for $C$. vettonica in general, as two of the four OCUs (III and IV) would be affected by this phenomenon. It could lead to the extinction of $C$. vettonica in these areas or to adaptive variations, resulting in a major loss of the genetic diversity of this species.

\section{Acknowledgments}

We want to thank P. Garzon, I. Doadrio Jr, J.L. Gonzalez and G. Gonzalez for collecting almost every sample from 2009 to 2010 under the project "Basis for the monitoring of Spanish Freshwater Fishes", supported by the Ministerio de Medio Ambiente y Medio Rural y Marino (MARM), and C. Marcos, J.C Velaco and G. Gonzalez for their help in the project Life13 nat/es/000772. We greatly thank L. Alcaraz for laboratory assistance. We are grateful for the valuable suggestions and English editing performed by M. Modrell. This study was also supported by a management commission funded by the Duero Hydrographic Confederation in Spain (Analisis y estudios filogeograficos y de variabilidad genetica de endemismos ibericos de ciprinidos: Life13 nat/es/000772 "Actuaciones para la proteccion y conservacion de ciprinidos ibericos de interes comunitario") and by grant IND2017/AMB-7699 to AC-L, funded by the Community of Madrid (Spain) through its Industrial Doctorate programme. We acknowledge the Santander Supercomputacion support group at the University of Cantabria for providing access to the supercomputer Altamira at the Institute of Physics of Cantabria (IFCA-CSIC), a member of the Spanish Supercomputing Network, which was used to perform simulations/analyses.

\section{References}

Abbott, R., Albach, D., Ansell, S., Arntzen, J. W., Baird, S. J., Bierne, N., .. \& \& Zinner, D. (2013). Hybridization and speciation. Journal of evolutionary biology, 26(2), 229-246.https://doi.org/10.1111/j.14209101.2012.02599.xAkaike, H (1974). A new look at the statistical model identification.IEEE transactions on automatic control, 19(6), 716-723.https://doi.org/10.1109/TAC.1974.1100705 Almodovar, A., Nicola, G. G., Leal, S., Torralva, M., \& Elvira, B (2012). Natural hybridization with invasive bleak Alburnus alburnus threatens the survival of Iberian endemic calandino Squalius alburnoides complex and Southern Iberian chub Squalius pyrenaicus. Biological Invasions, 14(11), 2237-2242.https://doi.org/10.1109/TAC.1974.1100705Alonso, J. L., Pulgar, F. J. A., \& Pedreira, D. (2007). The relief of the Cantabrian Mountains. Teaching Earth Sciences [In Spanish],15(2), 151163.https://doi.org/10.1109/TAC.1974.1100705Bandelt, H. J., Forster, P., \& Rohl, A. (1999). Medianjoining networks for inferring intraspecific phylogenies. Molecular biology and evolution, 16(1), 3748.https://doi.org/10.1093/oxfordjournals.molbev.a026036Beaulieu, J. M., Tank, D. C., \& Donoghue, M. J. (2013). A Southern Hemisphere origin for campanulid angiosperms, with traces of the break-up of Gondwana. BMC Evolutionary Biology, 13(1), 1-17.https://doi.org/10.1186/1471-2148-13-80Benito, G., Sopena, A., Sanchez-Moya, Y., Machado, M. J., \& Perez-Gonzalez, A. (2003). Palaeoflood record of the Tagus River (central Spain) during the Late Pleistocene and Holocene.Quaternary Science Reviews, 22(15-17), 1737-1756.https://doi.org/10.1016/S0277-3791(03)00133-1Bohlen, J., \& Rab, P. (2001). Species and hybrid richness in spined loaches of the genus Cobitis (Teleostei: Cobitidae), with a checklist of European forms and suggestions for conservation. Journal of Fish Biology, 59, 75-89.https://doi.org/10.1111/j.1095-8649.2001.tb01380.xBolger, A. M., Lohse, M., \& Usadel, B. (2014). Trimmomatic: a flexible trimmer for Illumina sequence data. Bioinformatics,30(15), 
2114-2120.https://doi.org/10.1093/bioinformatics/btu170Buj, I., Marčić, Z., Ćaleta, M., Šanda, R., Geiger, M. F., Freyhof, J., ... \& Vukić, J. (2017). Ancient connections among the European rivers and watersheds revealed from the evolutionary history of the genus Telestes (Actinopterygii; Cypriniformes). PLoS One,12(12), e0187366.https://doi.org/10.1371/journal.pone.0187366Carmona, J. A., Doadrio, I., Márquez, A. L., Real, R., Hugueny, B., \& Vargas, J. M. (1999). Distribution patterns of indigenous freshwater fishes in the Tagus River basin, Spain. Environmental Biology of Fishes, 54(4), 371-387.https://doi.org/10.1023/A:1007535200837Carmona, J. A., DomÍnguez, J., \& Doadrio, I. (2000). Congruence between allozyme and cytochrome b gene sequence data in assessing genetic differentiation within the Iberian endemic Chondrostoma lemmingii (Pisces: Cyprinidae). Heredity, 84(6), 721-732.https://doi.org/10.1046/j.1365-2540.2000.00720.xCarrasco, R. M., \& Pedraza, J. (1991). In the Jerte valley [In Spanish]. Cuaternario y Geomorfología, 5, 15-25.https://doi.org/10.1046/j.13652540.2000.00720.x Carrasco, R. M., Pedraza, J., Domínguez-Villar, D., Villa, J., \& Willenbring, J. K. (2013). The plateau glacier in the Sierra de Béjar (Iberian Central System) during its maximum extent. Reconstruction and chronology. Geomorphology, 196, 83-93.https://doi.org/10.1109/TAC.1974.1100705Carrasco, R. M., Pedraza, J., Dominguez-Villar, D., Willenbring, J. K., \& Villa, J. (2015). Sequence and chronology of the Cuerpo de Hombre paleoglacier (Iberian Central System) during the last glacial cycle.Quaternary Science Reviews, 129, 163-177.https://doi.org/10.1016/j.quascirev.2015.09.021Casal-Lopez, M., \& Doadrio, I. (2018). The Messinian imprint on the evolution of freshwater fishes of the genus Luciobarbus Heckel, 1843 (Teleostei, Cyprinidae) in the western Mediterranean. Journal of biogeography, 45(7), 15931603.https://doi.org/10.1111/jbi.13244Casal-Lopez, M., Perea, S., Sousa-Santos, C., Robalo, J. I., Torralva, M., Oliva-Paterna, F. J., \& Doadrio, I. (2017). Paleobiogeography of an Iberian endemic species, Luciobarbus sclateri (Gunther, 1868) (Actinopterygii, Cyprinidae), inferred from mitochondrial and nuclear markers.https://doi.org/10.1111/jzs.12192Casas-Sainz, A. M., \& De Vicente, G. (2009). On the tectonic origin of Iberian topography. Tectonophysics, 474(1-2), 214-235.https://doi.org/10.1016/j.tecto.2009.01.030Catchen, J. M., Hohenlohe, P. A., Bernatchez, L., Funk, W. C., Andrews, K. R., \& Allendorf, F. W. (2013). Stacks: an analysis tool set for population genomics. Molecular ecology, 22(11), 31243140.https://doi.org/10.1111/mec.12354Catchen, J., Hohenlohe, P. A., Bassham, S., Amores, A., \& Cresko, W. A. (2017). Unbroken: RADseq remains a powerful tool for understanding the genetics of adaptation in natural populations. Molecular ecology resources, 17(3), 362-365.https://doi.org/10.1111/17550998.12669Choleva, L., Musilova, Z., Kohoutova-Sediva, A., Paces, J., Rab, P., \& Janko, K. (2014). Distinguishing between incomplete lineage sorting and genomic introgressions: complete fixation of allospecific mitochondrial DNA in a sexually reproducing fish (Cobitis; Teleostei), despite clonal reproduction of hybrids. PLoS One, 9(6), e80641.https://doi.org/10.1371/journal.pone.0080641Collares-Pereira, M. J., Alves, M. J., Ribeiro, F., Domingos, I., Almeida, P. R., Da Costa, L., Gante, H., Filipe, A. F., Aboim, A., Rodrigues, P. M., Magalhaes, M. F. (2021). Guide to freshwater fish and migrants from mainland Portugal [In Portuguese]. Edicoes Afrontamento. Porto, 292 pp. Corral-Lou, A., Perea, S., \& Doadrio, I. (2021). High genetic differentiation in the endemic and endangered freshwater fish Achondrostoma salmantinum Doadrio and Elvira, 2007 from Spain, as revealed by mitochondrial and SNP markers. Conservation Genetics,22(4), 585-600.https://doi.org/10.1007/s10592-021-01381-yCorral-Lou, A., Perea, S., Aparicio, E., \& Doadrio, I. (2019). Phylogeography and species delineation of the genus Phoxinus Rafinesque, 1820 (Actinopterygii: Leuciscidae) in the Iberian Peninsula. Journal of Zoological Systematics and Evolutionary Research,57(4), 926941.https://doi.org/10.1111/jzs.12320Cunha, C., Coelho, M. M., Carmona, J. A., \& Doadrio, I. (2004). Phylogeographical insights into the origins of the Squalius alburnoides complex via multiple hybridization events. Molecular Ecology,13(9), 2807-2817.https://doi.org/10.1111/j.1365-294X.2004.02283.xDenys, G. P. J., Dettai, A., Persat, H., Doadrio, I., Cruaud, C., \& Keith, P. (2013). Status of the Catalan chub Squalius laietanus (Actinopterygii, Cyprinidae) in France: input from morphological and molecular data. Knowledge and Management of Aquatic Ecosystems, (408), 04.https://doi.org/10.1051/kmae/2013039Diez Herrero, A. (2018). Geomorphology and fluvial hydrology of the Alberche river: models and GIS for riverbank management [In Spanish]. Doadrio, I. (1988). Delimitation of areas in the Iberian Peninsula on the basis of freshwater fishes. Bonn Zool Beitr, 39, 113-128. Doadrio, I., \& Perdices, A. (1997). Taxonomic study of the Iberian Cobitis (Osteichthyes, Cobitidae), with description of a new species.Zoological Journal of the Linnean Society, 119(1), 
51-67.https://doi.org/10.1111/j.1096-3642.1997.tb00135.xDoadrio, I., \& Perdices, A. (2005). Phylogenetic relationships among the Ibero-African cobitids (Cobitis, Cobitidae) based on cytochrome b sequence data. Molecular Phylogenetics and Evolution,37(2), 484-493.https://doi.org/10.1016/j.ympev.2005.07.009Doadrio, I., Carmona, J. A., \& Machordom, A. (2002). Haplotype diversity and phylogenetic relationships among the Iberian barbels (Barbus, Cyprinidae) reveal two evolutionary lineages. Journal of Heredity, 93(2), 140-147.https://doi.org/10.1093/jhered/93.2.140Doadrio, I., Perea, S., \& Corral-Lou, A. (2021). Genetic characterization and identification of Conservation Units in endemic fish of community interest [In Spanish].http://hdl.handle.net/10261/241564Doadrio, I., Perea, S., Paloma, G. H., \& Gonzalez, J. L. (2011). Ictiofauna continental espanola: bases para su seguimiento, Ministerio de Medio Ambiente y Medio Rural y Marino. Centro de Publicaciones.DG Medio Natural y Politica Forestal. MARM., Madrid. Drummond, A. J., Suchard, M. A., Xie, D., \& Rambaut, A. (2012). Bayesian phylogenetics with BEAUti and the BEAST 1.7. Molecular biology and evolution, 29(8), 1969-1973.https://doi.org/10.1093/molbev/mss075Dudgeon, D. (2019). Multiple threats imperil freshwater biodiversity in the Anthropocene. Current Biology, 29(19), R960R967.https://doi.org/10.1016/j.cub.2019.08.002Ehrich, D., Gaudeul, M., Assefa, A., Koch, M. A., Mummenhoff, K., Nemomissa, S., .. \& \& Brochmann, C. (2007). Genetic consequences of Pleistocene range shifts: contrast between the Arctic, the Alps and the East African mountains. Molecular ecology, 16 (12), 25422559.https://doi.org/10.1111/j.1365-294X.2007.03299.xElith, J., H. Graham, C., P. Anderson, R., Dudik, M., Ferrier, S., Guisan, A., .. \& \& E. Zimmermann, N. (2006). Novel methods improve prediction of species' distributions from occurrence data.Ecography, 29(2), 129-151.https://doi.org/10.1111/j.2006.09067590.04596.xEvanno, G., Regnaut, S., \& Goudet, J. (2005). Detecting the number of clusters of individuals using the software STRUCTURE: a simulation study. Molecular ecology, 14(8), 26112620.https://doi.org/10.1111/j.1365-294X.2005.02553.xExcoffier, L., \& Lischer, H. E. (2010). Arlequin suite ver 3.5: a new series of programs to perform population genetics analyses under Linux and Windows. Molecular ecology resources, 10(3), 564-567.https://doi.org/10.1111/j.1755-0998.2010.02847.xFick, S. E., \& Hijmans, R. J. (2017). WorldClim 2: new 1-km spatial resolution climate surfaces for global land areas. International journal of climatology, 37(12), 4302-4315.https://doi.org/10.1002/joc.5086Frankham, R., Ballou, S. E. J. D., Briscoe, D. A., \& Ballou, J. D. (2002). Introduction to conservation genetics. Cambridge university press. Fu, Y. X. (1997). Statistical tests of neutrality of mutations against population growth, hitchhiking and background selection.Genetics, 147(2), 915-925.https://doi.org/10.1093/genetics/147.2.915Gante, H. F., Micael, J., Oliva-Paterna, F. J., Doadrio, I., Dowling, T. E., \& Alves, M. J. (2009). Diversification within glacial refugia: tempo and mode of evolution of the polytypic fish Barbus sclateri.Molecular ecology, 18(15), 3240-3255.https://doi.org/10.1111/j.1365-294X.2009.04264.xGante, H. M. F. (2009). A role for introgressive hybridization in the evolution of freshwater fishes: the case-study of Iberian Barbus (Teleostei, Cyprinidae). Arizona State University. Gibbard, P. L., Head, M. J., Walker, M. J., \& Subcommission on Quaternary Stratigraphy (2010). Formal ratification of the Quaternary System/Period and the Pleistocene Series/Epoch with a base at 2.58 Ma. Journal of Quaternary Science, 25(2), 96102.https://doi.org/10.1002/jqs.1338Gonzalez, E. G., Cunha, C., Ghanavi, H. R., Oliva-Paterna, F. J., Torralva, M., \& Doadrio, I. (2018). Phylogeography and population genetic analyses in the Iberian toothcarp (Aphanius iberus Valenciennes, 1846) at different time scales. Journal of Heredity,109(3), 253263.https://doi.org/10.1093/jhered/esx076Gonzalez, E. G., Pedraza-Lara, C., \& Doadrio, I. (2014). Genetic diversity and population history of the endangered killifish Aphanius baeticus. Journal of Heredity, 105(5), 597-610.https://doi.org/10.1093/jhered/esu034Goy, J. L., Cruz, R., Martinez-Grana, A., Valdes, V., \& Yenes, M. (2020). Geomorphological Map and Quaternary Landscape Evolution of the Monfrague Park (Caceres, Spain). Sustainability, 12(23), 10099.https://doi.org/10.3390/su122310099Hewitt, G. M. (1996). Some genetic consequences of ice ages, and their role in divergence and speciation. Biological journal of the Linnean Society, 58(3), 247-276.https://doi.org/10.1111/j.1095-8312.1996.tb01434.xHewitt, G. M. (2004). Genetic consequences of climatic oscillations in the Quaternary. Philosophical Transactions of the Royal Society of London. Series B: Biological Sciences, 359(1442), 183-195.https://doi.org/10.1098/rstb.2003.1388Hudson, R. R., Boos, D. D., \& Kaplan, N. L. (1992). A statistical test for detecting geographic subdivision. Molecular biology and evolution, 9(1), 138-151.https://doi.org/10.1093/oxfordjournals.molbev.a040703Janes, J. K., Miller, J. M., Dupuis, J. R., Malenfant, R. M., Gorrell, J. C., Cullingham, C. I., \& Andrew, R. L. (2017). 
The K= 2 conundrum.Molecular Ecology, 26(14), 3594-3602.https://doi.org/10.1111/mec.14187Janko, K., Culling, M. A., Rab, P., \& Kotlik, P. (2005). Ice age cloning-comparison of the Quaternary evolutionary histories of sexual and clonal forms of spiny loaches (Cobitis; Teleostei) using the analysis of mitochondrial DNA variation. Molecular Ecology,14(10), 2991-3004.https://doi.org/10.1111/j.1365-294X.2005.02583.xJanko, K., Flajšhans, M., Choleva, L., Bohlen, J., Šlechtová, V., Rábová, M., .. \& Rab, P. (2007). Diversity of European spined loaches (genus Cobitis L.): an update of the geographic distribution of the Cobitis taenia hybrid complex with a description of new molecular tools for species and hybrid determination. Journal of Fish Biology,71, 387-408.https://doi.org/10.1111/j.1095-8649.2007.01663.xJiménez, A. S. D. C. (1994). The mountain-lower surface contact in the southern slope of the Sierra de Gata (Spanish Central System, Cáceres) [In Spanish]. Cuaternario y Geomorfología, 8(1-2), 45-55. Katoh, K., \& Standley, D. M. (2013). MAFFT multiple sequence alignment software version 7: improvements in performance and usability.Molecular biology and evolution, 30(4), 772-780.https://doi.org/10.1093/molbev/mst010Kearse, M., Moir, R., Wilson, A., Stones-Havas, S., Cheung, M., Sturrock, S., .. \& \& Drummond, A. (2012). Geneious Basic: an integrated and extendable desktop software platform for the organization and analysis of sequence data. Bioinformatics, 28(12), 1647-1649.https://doi.org/10.1093/bioinformatics/bts199Kess, T., Gross, J., Harper, F., \& Boulding, E. G. (2016). Low-cost ddRAD method of SNP discovery and genotyping applied to the periwinkle Littorina saxatilis. Journal of Molluscan Studies, 82(1), 104-109.https://doi.org/10.1093/mollus/eyv042Lanfear, R., Frandsen, P. B., Wright, A. M., Senfeld, T., \& Calcott, B. (2017). PartitionFinder 2: new methods for selecting partitioned models of evolution for molecular and morphological phylogenetic analyses.Molecular biology and evolution, 34(3), 772-773.https://doi.org/10.1093/molbev/msw260Leigh, J. W., \& Bryant, D. (2015). popart: full-feature software for haplotype network construction. Methods in Ecology and Evolution, 6(9), 1110-1116.https://doi.org/10.1111/2041-210X.12410Li, Y. L., \& Liu, J. X. (2018). StructureSelector: A web-based software to select and visualize the optimal number of clusters using multiple methods. Molecular ecology resources, 18(1), 176-177.https://doi.org/10.1111/17550998.12719Machordom, A., Berrebi, P., \& Doadrio, I. (1990). Spanish barbel hybridization detected using enzymatic markers: Barbus meridionalis Rissox Barbus haasi Mertens (Osteichthyes, Cyprinidae). Aquatic Living Resources, 3(4), 295-303.https://doi.org/10.1051/alr:1990030Marić, S., Stanković, D., Šanda, R., Ćaleta, M., Čolić, S., Šukalo, G., \& Snoj, A. (2019). Genetic characterisation of European mudminnow (Umbra krameri) populations from the Sava River system. Knowledge 83 Management of Aquatic Ecosystems, (420), 46.https://doi.org/10.1051/kmae/2019035Marić, S., Stanković, D., Wanzenböck, J., Šanda, R., Erős, T., Takács, P., .. \& Snoj, A. (2017). Phylogeography and population genetics of the European mudminnow (Umbra krameri) with a time-calibrated phylogeny for the family Umbridae. Hydrobiologia, 792(1), 151-168.https://doi.org/10.1007/s10750-016-3051-9McCormack, J. E., Hird, S. M., Zellmer, A. J., Carstens, B. C., \& Brumfield, R. T. (2013). Applications of next-generation sequencing to phylogeography and phylogenetics. Molecular phylogenetics and evolution, 66(2), 526-538.https://doi.org/10.1016/j.ympev.2011.12.007Mendes, S. L., Coelho, M. M., \& Sousa, V. C. (2019). Population genomics data supports introgression between Western Iberian Squalius freshwater fish species from different drainages. bioRxiv, 585687. Mesquita, N., Hänfling, B., Carvalho, G. R., \& Coelho, M. M. (2005). Phylogeography of the cyprinid Squalius aradensis and implications for conservation of the endemic freshwater fauna of southern Portugal.Molecular Ecology, 14(7), 19391954.https://doi.org/10.1111/j.1365-294X.2005.02569.xMyers, G. S. (1938). Fresh water fishes and West Indian zoogeography (Vol. 3465). US Government Printing Office. Pais, J., Cunha, P. P., Pereira, D., Legoinha, P., Dias, R., Moura, D., ... \& González-Delgado, J. A. (2012). The Paleogene and Neogene of western Iberia (Portugal): a Cenozoic record in the European Atlantic domain. In The Paleogene and Neogene of Western Iberia (Portugal)(pp. 1-138). Springer, Berlin, Heidelberg.https://doi.org/10.1007/9783-642-22401-0_1Paris, J. R., Stevens, J. R., \& Catchen, J. M. (2017). Lost in parameter space: a road map for stacks. Methods in Ecology and Evolution, 8(10), 1360-1373.https://doi.org/10.1111/2041210X.12775 Perdices, A., \& Coelho, M. M. (2020). First records of the Vettonian spined loach Cobitis vettonica in Portugal with update on its Iberian distribution. Fishes in Mediterranean Environments 2020.002: 15p.https://doi.org/10.29094/FiSHMED.2020.002Perdices, A., \& Doadrio, I. (2001). The molecular systematics and biogeography of the European cobitids based on mitochondrial DNA sequences. Molecular 
Phylogenetics and Evolution, $19(3)$, 468-478.https://doi.org/10.1006/mpev.2000.0900Perea, S., \& Doadrio, I. (2015). Phylogeography, historical demography and habitat suitability modelling of freshwater fishes inhabiting seasonally fluctuating Mediterranean river systems: a case study using the Iberian cyprinid Squalius valentinus. Molecular Ecology,24(14), 3706-3722.https://doi.org/10.1109/TAC.1974.1100705Perea, S., Cobo-Simon, M., \& Doadrio, I. (2016). Cenozoic tectonic and climatic events in southern Iberian Peninsula: Implications for the evolutionary history of freshwater fish of the genus Squalius (Actinopterygii, Cyprinidae). Molecular Phylogenetics and Evolution, 97, 155-169.https://doi.org/10.1016/j.ympev.2016.01.007Perea, S., Sousa-Santos, C., Robalo, J., \& Doadrio, I. (2021). Historical biogeography of the Iberian Peninsula: multilocus phylogeny and ancestral area reconstruction for the freshwater fish genus Squalius (Actinopterygii, Leuciscidae). Journal of Zoological Systematics and Evolutionary Research, 59(4), 858886.https://doi.org/10.1111/jzs.12464Perez-Gonzalez, A. (1980). Geology and stratigraphy of the Aridos deposits in the alluvial plain of Arganda (Madrid) [In Spanish].In Ocupaciones achelenses en el valle del Jarama (Arganda-Madrid)(pp. 49-62). Phillips, S. J., Anderson, R. P., Dudik, M., Schapire, R. E., \& Blair, M. E. (2017). Opening the black box: An open-source release of Maxent.Ecography, 40(7), 887893.https://doi.org/10.1111/ecog.03049Pillans, B., \& Naish, T. (2004). Defining the quaternary. Quaternary Science Reviews, 23(23-24), 2271-2282.https://doi.org/10.1016/j.quascirev.2004.07.006Pritchard, J. K., Stephens, M., \& Donnelly, P. (2000). Inference of population structure using multilocus genotype data. Genetics,155(2), 945-959.https://doi.org/10.1093/genetics/155.2.945Puechmaille, S. J. (2016). The program structure does not reliably recover the correct population structure when sampling is uneven: subsampling and new estimators alleviate the problem. Molecular ecology resources, 16(3), 608-627.https://doi.org/10.1111/1755-0998.12512Querejeta, M., Fernandez-Gonzalez, A., Romero, R., \& Castresana, J. (2017). Postglacial dispersal patterns and mitochondrial genetic structure of the Pyrenean desman (Galemys pyrenaicus) in the northwestern region of the Iberian Peninsula. Ecology and evolution, 7(12), 4486-4495.https://doi.org/10.1002/ece3.3034Rab, P. \& Slavik, O. (1996). Diploid-triploid-tetraploid complex of the spined loach, genus Cobitis in Provka Creek: the first evidence of new species of Cobitis in the ichthyofauna of the Czech Republic. Acta Univ Carol (Biol), 39, 201-214. Ree, R. H., \& Smith, S. A. (2008). Maximum likelihood inference of geographic range evolution by dispersal, local extinction, and cladogenesis. Systematic biology, 57(1), 414.https://doi.org/10.1080/10635150701883881Rodríguez, R., Ramirez, O., Valdiosera, C. E., Garcia, N., Alda, F., Madurell-Malapeira, J., ... \& Dalen, L. (2011). 50,000 years of genetic uniformity in the critically endangered Iberian lynx. Molecular Ecology, 20(18), 3785-3795.https://doi.org/10.1111/j.1365294X.2011.05231.xRonquist, F., Teslenko, M., Van Der Mark, P., Ayres, D. L., Darling, A., Hohna, S., ... \& Huelsenbeck, J. P. (2012). MrBayes 3.2: efficient Bayesian phylogenetic inference and model choice across a large model space. Systematic biology, 61(3), 539-542.https://doi.org/10.1093/sysbio/sys029Rozas, J., Ferrer-Mata, A., Sanchez-DelBarrio, J. C., Guirao-Rico, S., Librado, P., Ramos-Onsins, S. E., \& Sanchez-Gracia, A. (2017). DnaSP 6: DNA sequence polymorphism analysis of large data sets. Molecular biology and evolution, 34(12), 3299-3302.https://doi.org/10.1093/molbev/msx248Schnabel, S., \& Gutierrez, A. G. (2014). Advances in Geomorphology in Spain 2012-2014 [In Spanish]. Actas de la XIII Reunion Nacional de Geomorfologia. Caceres, Universidad de Extremadura-Sociedad Espanola de Geomorfologia. Seifertova, M., Bryja, J., Vyskočilová, M., Martínková, N., \& Šimková, A. (2012). Multiple Pleistocene refugia and post-glacial colonization in the European chub (Squalius cephalus) revealed by combined use of nuclear and mitochondrial markers. Journal of Biogeography,39(6), 10241040.https://doi.org/10.1111/j.1365-2699.2011.02661.xSousa-Santos, C., Collares-Pereira, M. J., \& Almada, V. (2007). Reading the history of a hybrid fish complex from its molecular record.Molecular phylogenetics and evolution, 45(3), 981-996.https://doi.org/10.1016/j.ympev.2007.05.011Sousa-Santos, C., Jesus, T. F., Fernandes, C., Robalo, J. I., \& Coelho, M. M. (2019). Fish diversification at the pace of geomorphological changes: evolutionary history of western Iberian Leuciscinae (Teleostei: Leuciscidae) inferred from multilocus sequence data. Molecular phylogenetics and evolution, 133, 263285.https://doi.org/10.1016/j.ympev.2018.12.020Sousa-Santos, C., Robalo, J. I., \& Pereira, A. (2014). Threatened fishes of the world: Cobitis vettonica Doadrio \& Perdices, 1997 (Cobitidae). Croatian Journal of Fisheries, 72(4), 174-175.https://doi.org/10.1109/TAC.1974.1100705Stamatakis, A. (2016). The 
RAxML v8. 2. X Manual. Heidleberg Institute for Theoretical Studies. Available at: https://cme. hits. org/exelixis/resource/download/NewManual. pdf.https://doi.org/10.1109/TAC.1974.1100705Stephens, M., \& Donnelly, P. (2003). A comparison of bayesian methods for haplotype reconstruction from population genotype data. The American Journal of Human Genetics, 73(5), 11621169.https://doi.org/10.1086/379378Stephens, M., Smith, N. J., \& Donnelly, P. (2001). A new statistical method for haplotype reconstruction from population data. The American Journal of Human Genetics, 68(4), 978-989.https://doi.org/10.1086/319501Swets, J. A. (1988). Measuring the accuracy of diagnostic systems.Science, 240(4857), 1285-1293.https://doi.org/10.1109/TAC.1974.1100705Taberlet, P., \& Bouvet, J. (1994). Mitochondrial DNA polymorphism, phylogeography, and conservation genetics of the brown bear Ursus arctos in Europe. Proceedings of the Royal Society of London. Series B: Biological Sciences, 255(1344), 195-200.https://doi.org/10.1098/rspb.1994.0028Tajima, F. (1989). Statistical method for testing the neutral mutation hypothesis by DNA polymorphism. Genetics, 123(3), 585-595. Tamura, K., Stecher, G., Peterson, D., Filipski, A., \& Kumar, S. (2013). MEGA6: molecular evolutionary genetics analysis version 6.0.Molecular biology and evolution, 30(12), 2725-2729.https://doi.org/10.1093/molbev/mst197Tan, M. P., Wong, L. L., Razali, S. A., Afiqah-Aleng, N., Mohd Nor, S. A., Sung, Y. Y., .. \& DanishDaniel, M. (2019). Applications of next-generation sequencing technologies and computational tools in molecular evolution and aquatic animals conservation studies: a short review. Evolutionary Bioinformatics, 15, 1176934319892284.https://doi.org/10.1177/11769343198922844Tancioni, L., Russo, T., Cataudella, S., Milana, V., Hett, A. K., Corsi, E., \& Rossi, A. R. (2013). Testing species delimitations in four Italian sympatric leuciscine fishes in the Tiber River: a combined morphological and molecular approach. PloS one, 8(4), e60392.https://doi.org/10.1371/journal.pone.0060392Valdiosera, C. E., Garcia-Garitagoitia, J. L., Garcia, N., Doadrio, I., Thomas, M. G., Hanni, C., ... \& Gotherstrom, A. (2008). Surprising migration and population size dynamics in ancient Iberian brown bears (Ursus arctos). Proceedings of the National Academy of Sciences,105(13), 5123-5128.https://doi.org/10.1073/pnas.0712223105Weiss, S., \& Ferrand, N. (2007). Phylogeography of southern European refugia (pp. 341-357). Dordrecht: Springer. Wetjen, M., Hubner, D., Seehausen, O., \& Schulz, R. (2020). Genetic diversity of endangered Chondrostoma nasus in the River Rhine system: Conservation genetics considerations on stocking and reintroduction.Knowledge $\&$ Management of Aquatic Ecosystems, (421), 25.https://doi.org/10.1051/kmae/2020016Yu, Y., Blair, C., \& He, X. (2020). RASP 4: ancestral state reconstruction tool for multiple genes and characters. Molecular Biology and Evolution, 37(2), 604606.https://doi.org/10.1093/molbev/msz257Yu, Y., Harris, A. J., \& He, X. (2010). S-DIVA (Statistical Dispersal-Vicariance Analysis): a tool for inferring biogeographic histories. Molecular phylogenetics and Evolution, 56(2), 848-850.https://doi.org/10.1016/j.ympev.2010.04.011Yu, Y., Harris, A. J., Blair, C., \& He, X. (2015). RASP (Reconstruct Ancestral State in Phylogenies): a tool for historical biogeography.Molecular phylogenetics and evolution, 87, 46-49.https://doi.org/10.1016/j.ympev.2015.03.008Zarraonaindia, I., Iriondo, M., Albaina, A., Pardo, M. A., Manzano, C., Grant, W. S., . . \& Estonba, A. (2012). Multiple SNP markers reveal fine-scale population and deep phylogeographic structure in European anchovy (Engraulis encrasicolus L.). PloS one, 7(7), e42201.https://doi.org/10.1371/journal.pone.0042201

\section{Data Accessibility and Benefit-Sharing Statement}

The new sequences of the mitochondrial (MT-CYTB ) and nuclear (RAG1) markers obtained from this study are available in GenBank (pending). The SNP data have been deposited in VCF format in Figshare (pending).

\section{Author Contributions}

I. D. designed the research and revised the manuscript. A.C.L. collected data, made the analyses and wrote the manuscript. S.P. helped to make the analyses and to draft the manuscript. A.P. revised the manuscript and make useful suggestions for it. All authors read and approved the final version of the manuscript.

\section{Tables and Figures}

Table 1. Information on the sampling localities included in the present study. Also detailed are the number 
of individuals studied for each of the marker types: mtDNA (MT-CYB), nDNA (RAG1) and SNPs. Under the mtDNA column, for each sympatric area, the two numbers indicate the number of individuals analysed for C. vettonica and C. paludica, respectively.

\begin{tabular}{|c|c|c|c|c|c|c|c|}
\hline $\mathrm{N}^{\mathrm{Q}}$ & Species & River & Basin & Sub-basin & Locality & Province & mtDNA \\
\hline 1 & Sympatric area & Alfrividas & Tagus & Ponsul & Alfrividas & Portugal & $4 / 1$ \\
\hline 2 & C. vettonica & Aravil & Tagus & Aravil & Alcafozes & Portugal & 1 \\
\hline 3 & C. vettonica & Aravil & Tagus & Aravil & Cegonhas Novas & Portugal & 4 \\
\hline 4 & C. vettonica & Erjas & Tagus & Upper Erjas & Valverde del Fresno & Spain & 12 \\
\hline 5 & C. vettonica & San Martin & Tagus & Upper Erjas & San Martín de Trevejo & Spain & 6 \\
\hline 6 & C. vettonica & Trevejana & Tagus & Upper Erjas & Cilleros & Spain & 4 \\
\hline 7 & C. vettonica & Erjas & Tagus & Middle Erjas & Termas de Monfortinho & Portugal & 6 \\
\hline 8 & C. vettonica & Arades & Tagus & Middle Erjas & Salvaterra do Extremo & Portugal & 2 \\
\hline 9 & C. vettonica & Erjas & Tagus & Lower Erjas & Salvaterra do Extremo & Portugal & 2 \\
\hline 10 & Sympatric area & Erjas & Tagus & Lower Erjas & Cabeça Queimado & Portugal & $1 / 1$ \\
\hline 11 & Sympatric area & Erjas & Tagus & Lower Erjas & Azenha do Roque & Portugal & $4 / 1$ \\
\hline 12 & Sympatric area & Erjas & Tagus & Lower Erjas & Serrinha & Portugal & $2 / 1$ \\
\hline 13 & C. vettonica & Árrago & Tagus & Western Alagón & Cadalso de Gata & Spain & 15 \\
\hline 14 & C. vettonica & Gata & Tagus & Western Alagón & Gata & Spain & 19 \\
\hline 15 & C. vettonica & San Blas & Tagus & Western Alagón & Gata & Spain & 1 \\
\hline 16 & C. vettonica & Acebo & Tagus & Western Alagón & Hoyos & Spain & 3 \\
\hline 17 & C. vettonica & Mayas & Duero & Águeda & Descargamaría & Spain & 2 \\
\hline 18 & C. vettonica & Mayas & Duero & Águeda & El Sahugo & Spain & 20 \\
\hline 19 & C. vettonica & Águeda & Duero & Águeda & La Herguijuela & Spain & 1 \\
\hline 20 & C. vettonica & Turones & Duero & Águeda & La Bouza & Spain & 1 \\
\hline 21 & C. vettonica & Alagón & Tagus & Eastern Alagón & Santi Ibañez de la Sierra & Spain & 14 \\
\hline 22 & C. vettonica & Francia & Tagus & Eastern Alagón & Nava de Francia & Spain & 14 \\
\hline 23 & C. vettonica & Cuerpo de Hombre & Tagus & Eastern Alagón & Sotoserrano & Spain & 19 \\
\hline 24 & C. vettonica & Ladrillar & Tagus & Eastern Alagón & La Rebollosa & Spain & 1 \\
\hline 25 & C. vettonica & Hurdano & Tagus & Eastern Alagón & Vegas de Coria & Spain & 1 \\
\hline 26 & C. vettonica & Caparro & Tagus & Eastern Alagón & Zarza de Granadilla & Spain & 23 \\
\hline 27 & C. vettonica & Jerte & Tagus & Eastern Alagón & Navaconcejo & Spain & 15 \\
\hline 28 & C. paludica & Alvito & Tagus & Ocreza & Monte Gordo & Portugal & 1 \\
\hline 29 & C. paludica & Aurela & Tagus & Salor & Santiago de Alcántara & Spain & 5 \\
\hline 30 & C. paludica & Toula & Tagus & Aravil & Alcafozes & Portugal & 1 \\
\hline 31 & C. paludica & Aravil & Tagus & Aravil & Cegonhas Novas & Portugal & 1 \\
\hline 32 & C. paludica & Salor & Tagus & Salor & Membrío & Spain & 2 \\
\hline 33 & C. paludica & Tamuja & Tagus & Almonte & Trujillo & Spain & 4 \\
\hline 34 & C. paludica & Almonte & Tagus & Almonte & Jaraicejo & Spain & 5 \\
\hline 35 & C. paludica & Ibor & Tagus & Lower Tagus & Castañar de Ibor & Spain & 3 \\
\hline 36 & C. paludica & Tiétar & Tagus & Tiétar & La Iglesuela del Tiétar & Spain & 11 \\
\hline 37 & C. paludica & Yeltes & Duero & Huebra-Yeltes & San Martín de Yeltes & Spain & 5 \\
\hline 38 & C. paludica & Huebra & Duero & Huebra-Yeltes & El cubo de don Sancho & Spain & 9 \\
\hline
\end{tabular}

Table 2. Genetic variability parameters for $M T-C Y B$ and $R A G 1$ and the results of the neutrality tests of Tajima and $\mathrm{Fu}$ and $\mathrm{Li}$ for the different groups (see text for details). The following parameters are included in the table for $M T-C Y B: \mathrm{N}$ : number of analysed samples; $h:$ haplotype number; $H d:$ haplotype diversity; $\pi$ : nucleotide diversity; $S$ : number of polymorphic sites. The following parameters are included in the table for RAG1 : N: number of analysed samples; $a$ : number of nuclear alleles; $a_{d}$ : allelic diversity; $\pi$ : nucleotide diversity; $S$ : number of polymorphic sites. Abbreviations; R. for river and S. for sub-basin. 


\begin{tabular}{|c|c|c|c|c|c|c|c|c|}
\hline & MT-CYB & MT-CYB & MT-CYB & MT-CYB & MT-CYB & MT-CYB & MT-CYB & $\mathrm{RAC}$ \\
\hline General & $\mathbf{N}$ & $\mathrm{h}$ & $\mathrm{H}_{\mathrm{d}}$ & $\pi$ & S & Tajima's $D$ & Fu's $F S$ & $\mathbf{N}$ \\
\hline C. vettonica & 150 & 31 & 0.85 & $5.86 \mathrm{E}-03$ & 38 & -0.18 & -4.8 & 45 \\
\hline By locality & $\mathbf{N}$ & $\mathrm{h}$ & $\mathrm{H}_{\mathrm{d}}$ & $\pi$ & $\mathrm{S}$ & Tajima's $D$ & Fu's $F S$ & $\mathbf{N}$ \\
\hline Alfrividas R. & 4 & 2 & 0.5 & $9.20 \mathrm{E}-04$ & 2 & -0.70 & 1.09 & - \\
\hline Aravil R. & 5 & 2 & 0.4 & $3.70 \mathrm{E}-04$ & 1 & -0.81 & 0.09 & - \\
\hline Upper Erjas R. & 12 & 4 & 0.46 & $4.60 \mathrm{E}-04$ & 3 & $-1.62^{*}$ & $-2.12^{*}$ & 9 \\
\hline San Martin R. & 6 & 2 & 0.33 & $6.10 \mathrm{E}-04$ & 2 & -1.13 & 0.95 & 1 \\
\hline Trevejana R. & 4 & 2 & 0.5 & $4.60 \mathrm{E}-04$ & 1 & -0.61 & 0.17 & 4 \\
\hline Middle Erjas R. & 6 & 6 & 1 & $1.78 \mathrm{E}-03$ & 5 & -0.65 & $-4.45^{*}$ & - \\
\hline Lower Erjas S. & 9 & 7 & 0.92 & $1.94 \mathrm{E}-03$ & 8 & -1.28 & $-3.61^{*}$ & - \\
\hline Arades R. & 2 & 1 & 0 & 0 & 0 & - & - & - \\
\hline Árrago R. & 15 & 3 & 0.36 & $3.50 \mathrm{E}-04$ & 2 & -1.00 & -0.91 & 3 \\
\hline Gata R. & 18 & 5 & 0.72 & $1.05 \mathrm{E}-03$ & 4 & -0.04 & -0.91 & 5 \\
\hline San Blas R. & 1 & 1 & - & - & - & - & - & - \\
\hline Acebo R. & 3 & 1 & 0 & 0 & 0 & - & - & 1 \\
\hline Mayas R. & 22 & 1 & 0 & 0 & 0 & - & - & 4 \\
\hline Águeda R. & 1 & 1 & - & - & - & - & - & - \\
\hline Turones R. & 1 & 1 & - & - & - & - & - & 1 \\
\hline Alagón R. & 7 & 5 & 0.86 & $1.31 \mathrm{E}-03$ & 5 & $-1.48^{*}$ & $-2.31^{*}$ & 6 \\
\hline Francia R. & 8 & 2 & 0.25 & $2.30 \mathrm{E}-04$ & 1 & -1.05 & -0.18 & 1 \\
\hline Cdh R. & 10 & 2 & 0.36 & $3.30 \mathrm{E}-04$ & 1 & 0.01 & 0.41 & 4 \\
\hline Ladrillar R. & 1 & 1 & - & - & - & - & - & - \\
\hline Hurdano R. & 1 & 1 & - & - & - & - & - & 1 \\
\hline Caparro R. & 6 & 1 & 0 & 0 & 0 & - & - & 2 \\
\hline Jerte R. & 8 & 2 & 0.25 & $9.20 \mathrm{E}-04$ & 4 & $-1.53^{*}$ & 1.94 & 3 \\
\hline By sub-basin & $\mathbf{N}$ & $\mathbf{h}$ & $\mathbf{H}_{\mathrm{d}}$ & $\pi$ & S & Tajima's $D$ & Fu's $F S$ & $\mathbf{N}$ \\
\hline Ponsul S. & 4 & 2 & 0.5 & $9.20 \mathrm{E}-04$ & 2 & -0.71 & 1.09 & - \\
\hline Aravil S. & 5 & 2 & 0.4 & $3.70 \mathrm{E}-04$ & 1 & -0.81 & 0.09 & - \\
\hline Erjas S. & 39 & 14 & 0.66 & $1.03 \mathrm{E}-03$ & 12 & $-1.87^{*}$ & $-12.04^{*}$ & 14 \\
\hline Águeda S. & 24 & 1 & 0 & 0 & 0 & 0 & 0 & 5 \\
\hline Alagón S. & 78 & 15 & 0.781 & $2.12 \mathrm{E}-03$ & 17 & -0.96 & $-4.34^{*}$ & 26 \\
\hline Western Alagón S. & 37 & 7 & 0.71 & $8.60 \mathrm{E}-04$ & 6 & -0.94 & $-2.62^{*}$ & - \\
\hline Eastern Alagón S. & 41 & 8 & 0.43 & $7.00 \mathrm{E}-04$ & 11 & $-2.12^{*}$ & $-4.56^{*}$ & - \\
\hline By lineage $(M T-C Y B)$ & $\mathbf{N}$ & $\mathbf{h}$ & $\mathbf{H}_{\mathbf{d}}$ & $\pi$ & $\mathbf{S}$ & Tajima's $D$ & Fu's $F S$ & $\mathbf{N}$ \\
\hline V1 & 62 & 8 & 0.56 & $6.00 \mathrm{E}-04$ & 7 & -1.42 & $-4.54^{*}$ & 15 \\
\hline $\mathrm{V} 2$ & 40 & 7 & 0.4 & $5.40 \mathrm{E}-04$ & 9 & $-2.11^{*}$ & $-4.36^{*}$ & 16 \\
\hline V3 & 48 & 16 & 0.61 & $9.60 \mathrm{E}-04$ & 15 & $-2.14^{*}$ & $-15.53^{*}$ & 14 \\
\hline
\end{tabular}

Figure 1. Sampling localities included in this study. The orange shading delimits the Duero Basin, and the green shading delimits the Tagus Basin. Numbers correspond to those listed in Table 1. 


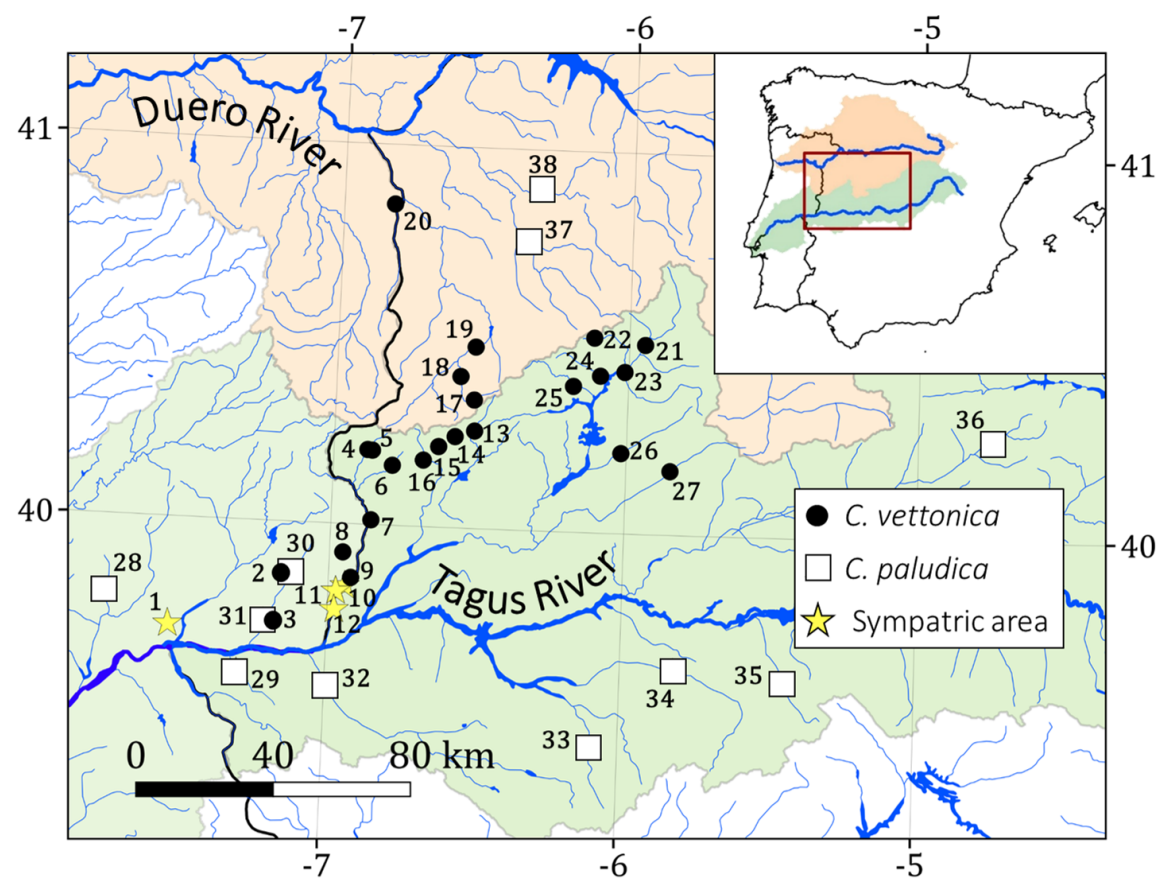

Figure 2. Phylogenetic relationships and divergence time estimates based on the analysis of the mitochondrial marker $M T-C Y B$ in BEAST. The horizontal bars represent the $95 \%$ HPD intervals. Posterior probabilities of the main nodes are indicated above branches. S1: Cobitis vettonica. The vertical coloured bars represent the three main lineages $(\mathrm{V} 1-\mathrm{V} 3)$ of the species and their localities (see legend). S2: Cobitis paludica. On the right, images of representative specimens belonging to one of the localities of each lineage: (from top to bottom): Caparro, Gata, middle Erjas and Tiétar rivers.

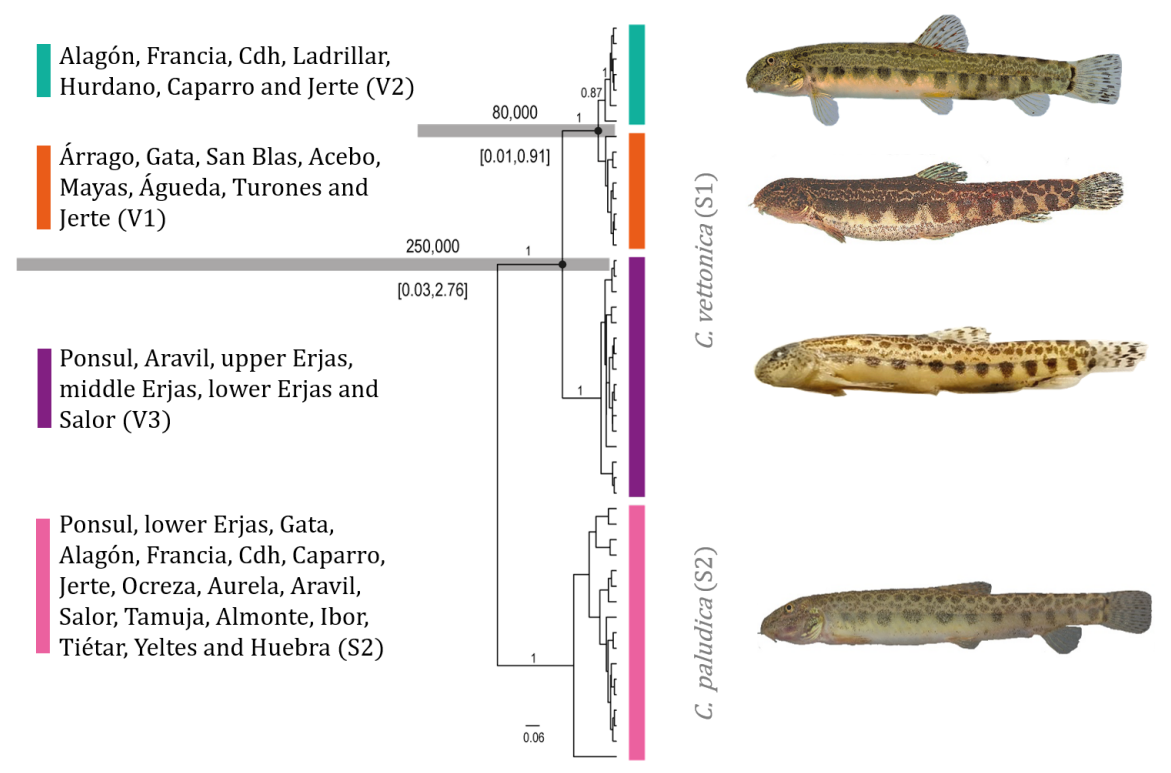




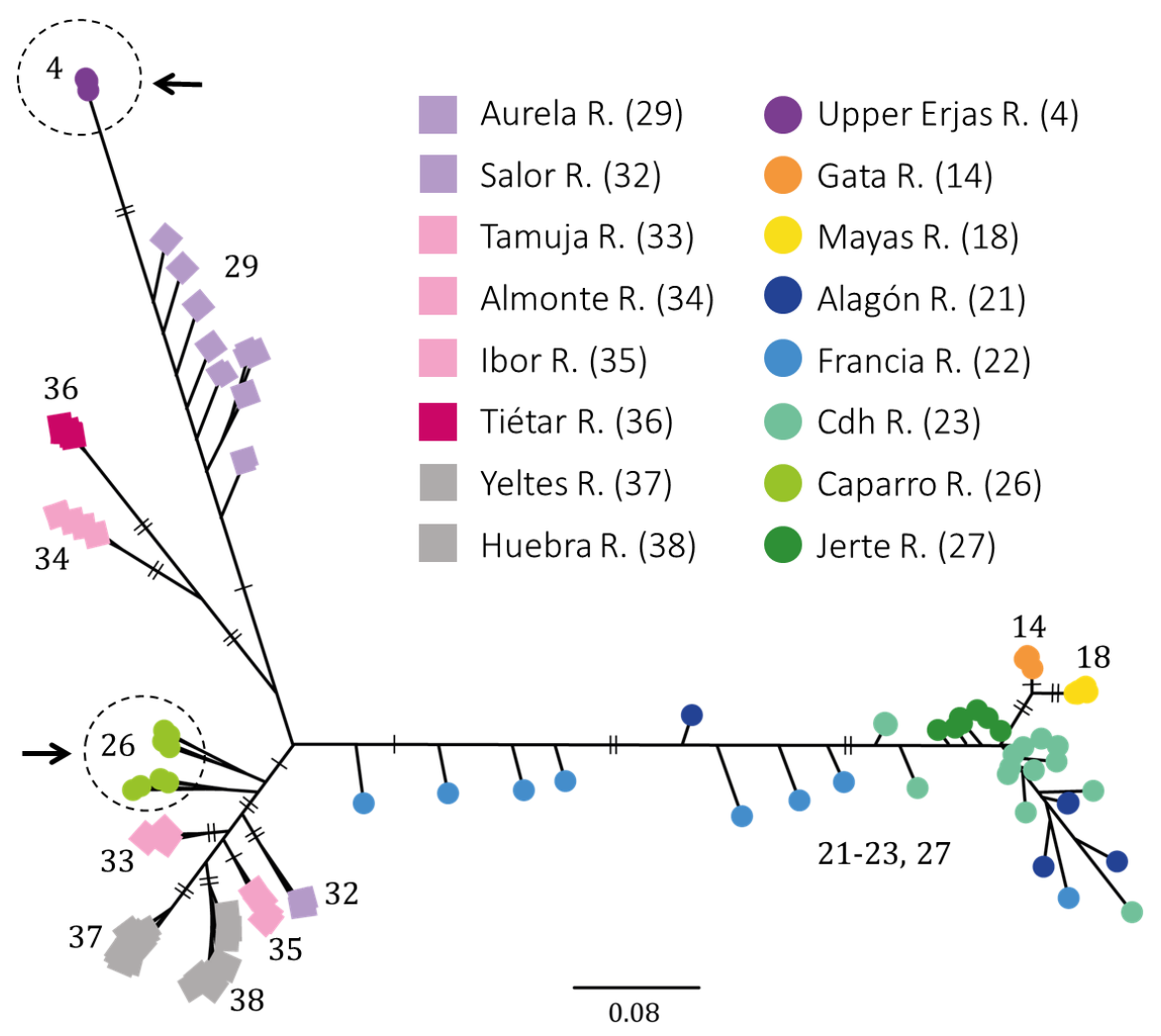

Figure 3. Unrooted ML phylogenetic tree based on the 4,538 SNP loci. Circles and squares indicate individuals morphologically identified as C. vettonica and C. paludica, respectively. The numbers refer to those assigned to the populations in Table 1. The bootstrap values (b) are represented with a line perpendicular to the branch for $75<\mathrm{b}>90$, and two lines for $\mathrm{b}>90$. The arrows highlight the populations of C. vettonica from the Caparro () and upper Erjas () rivers. Abbreviation; R. for river.

Figure 4. Haplotype network for the mitochondrial marker $M T-C Y B$. The localities are indicated by different colours and numbers (see Table 1). Mutational steps are represented as follows: one short line for 2 steps, two short lines for 3 steps or a circle with the number of steps indicated for 4 or more steps. V4* refers only to those individuals identified as C. vettonica and found in the S2 lineage (individuals indicated by pink are not included in $\mathrm{V} 4 *$ ). In the legend, populations identified as $C$. vettonica are represented by circles, and those identified as C. paludica, by squares. Populations that contain individuals with contrasting morphological and genetic identifications are underlined. Abbreviations; R. for river; S. for sub-basin and B. for basin. 


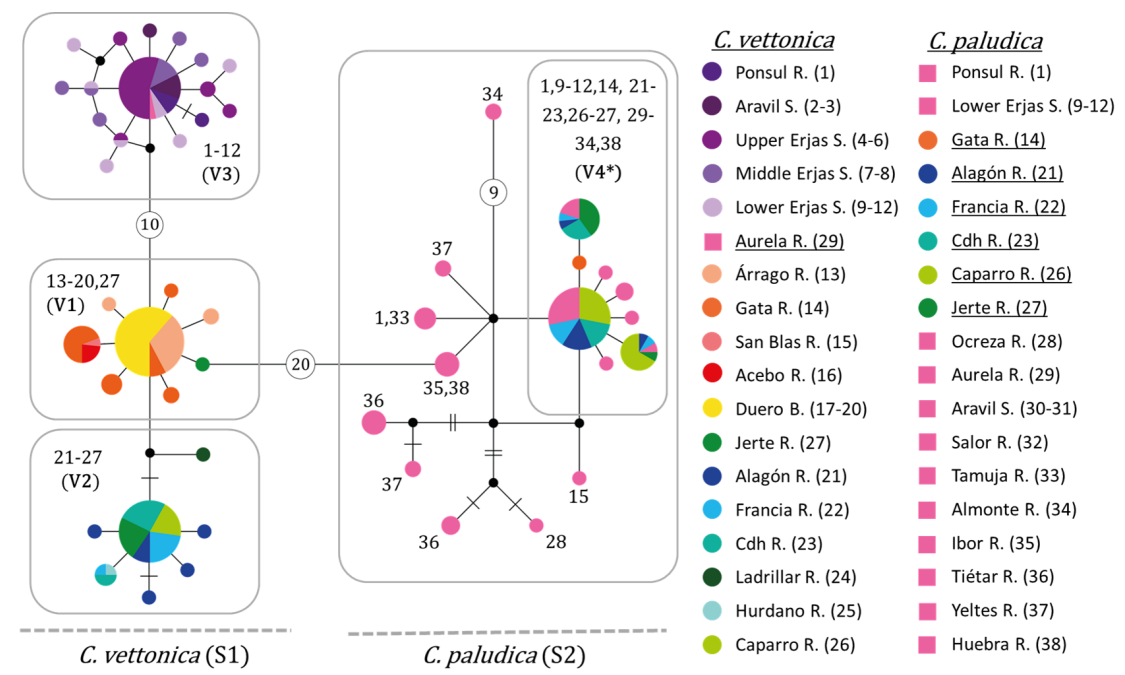

Figure 5. Results of the STRUCTURE analyses. The first graph shows the results obtained when $\mathrm{K}=4$ and only the populations of $C$. vettonica were analysed (1-8). The second graph shows the results obtained when $\mathrm{K}=6$ and populations of both $C$. vettonica (1-8) and C. paludica (9-16) were analysed. Abbreviation; R. for river.
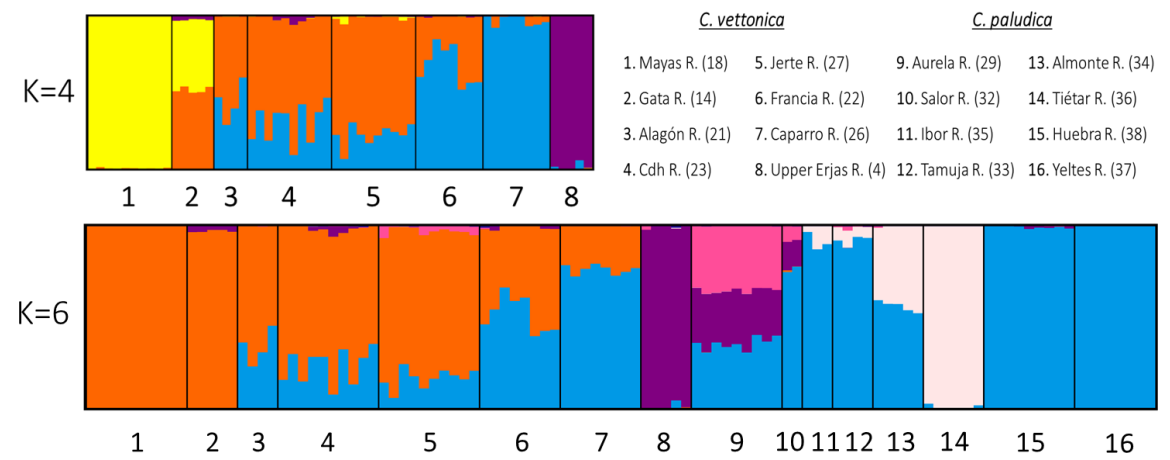

Figure 6. Modelling of the potential niche of C. vettonica for A) and B) the present (1970-2000) at a resolution of 30 seconds (s) and 2.5 minutes (m), respectively, C) Last Interglacial (LIG; 130,000 years ago) and D) Last Glacial Maximum (LGM; 22,000 years ago). The colours indicate the probability of the presence of the species (see legend). Some of the rivers (R.) mentioned in the text are labelled. 

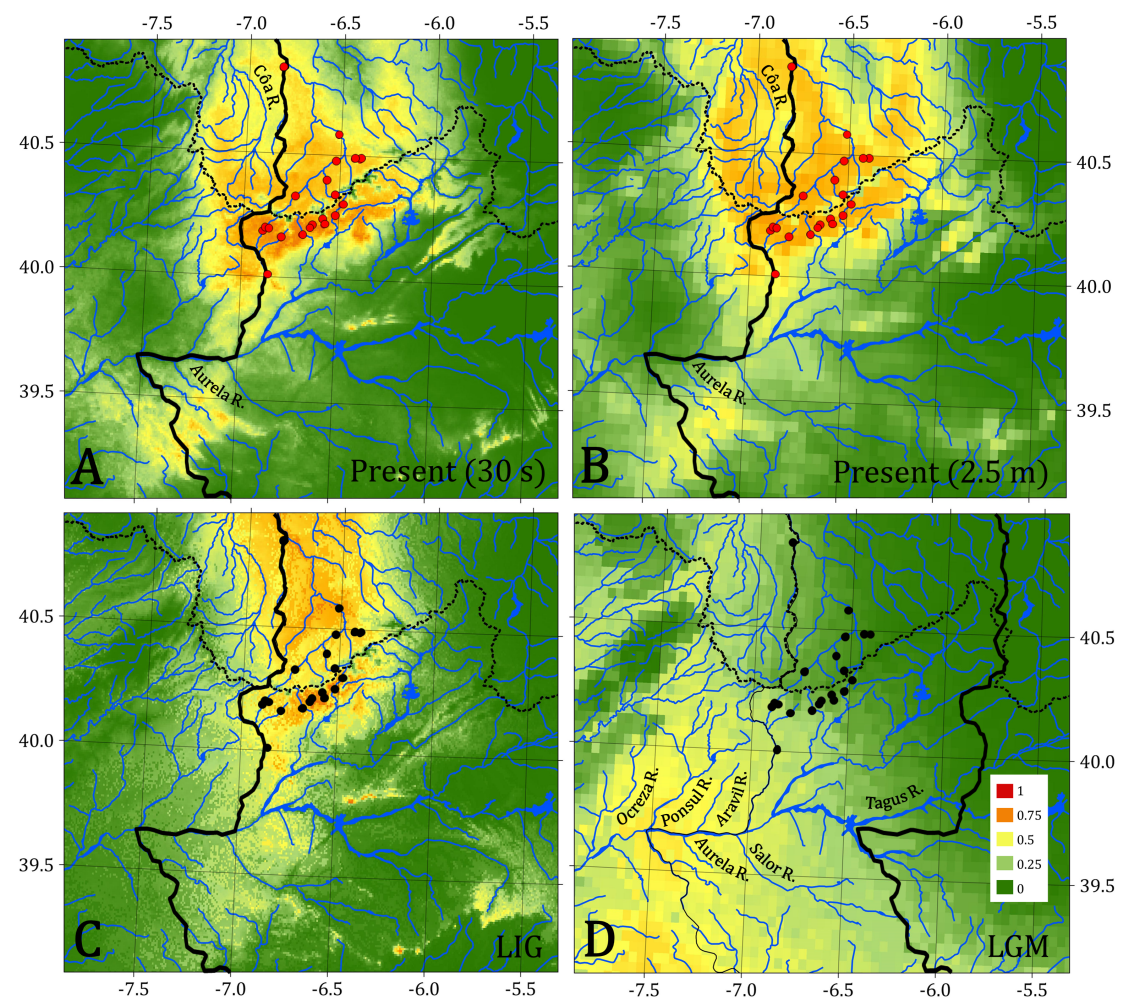

Figure 7. 3D map indicating the sampling locations referenced in Table 1. The colour of the sampling point indicates the OCU (I to IV) to which it is assigned. Some of the main rivers sampled in the study are also indicated on the map.

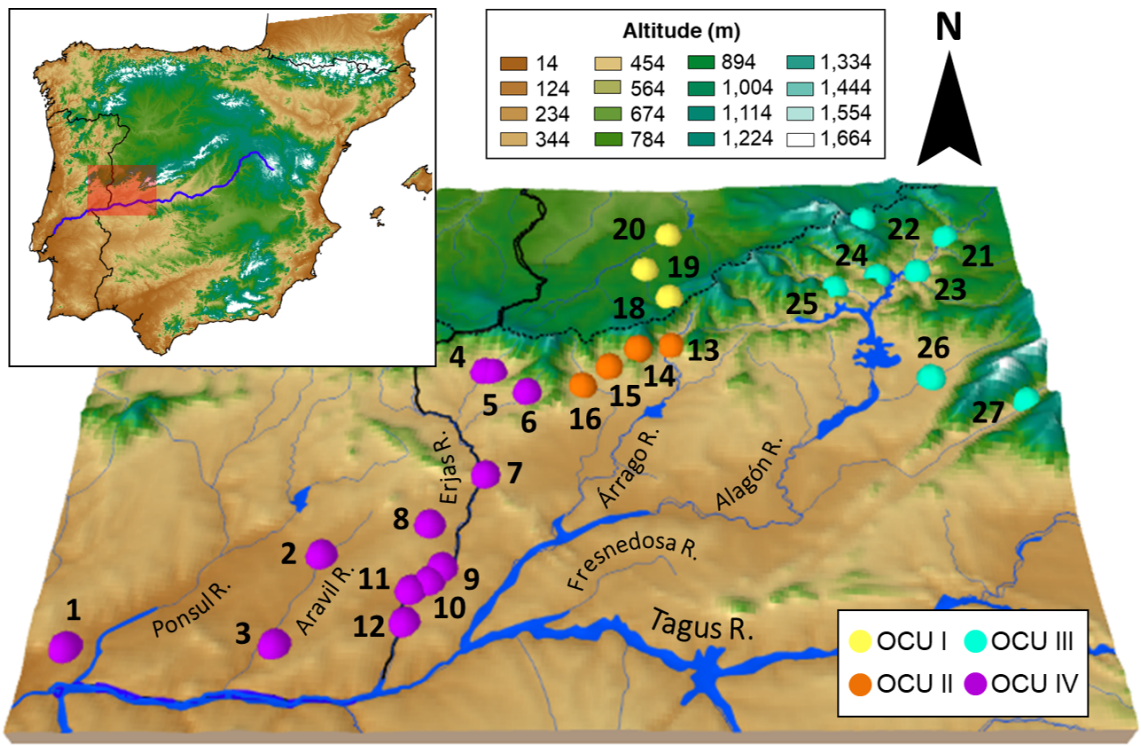



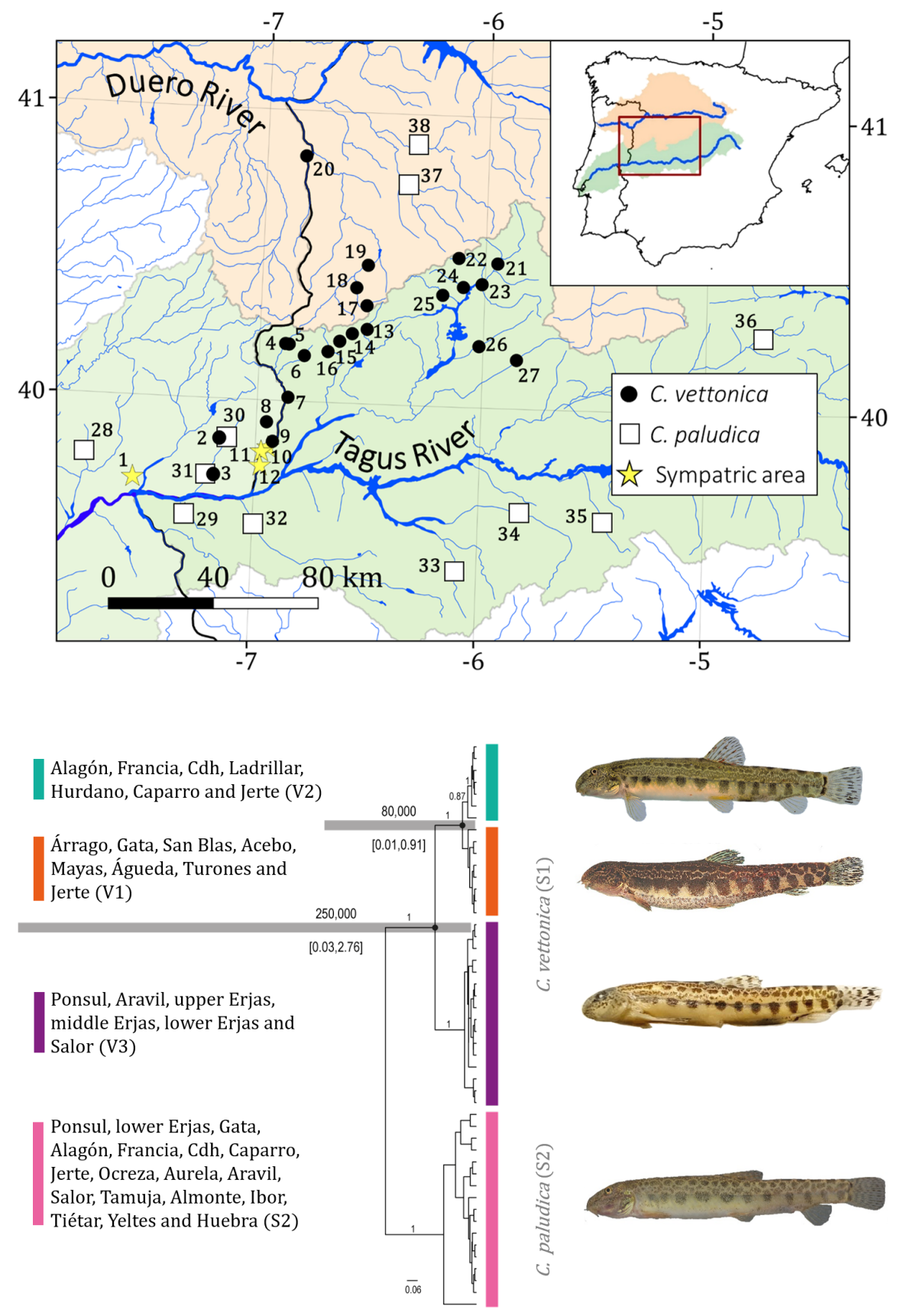

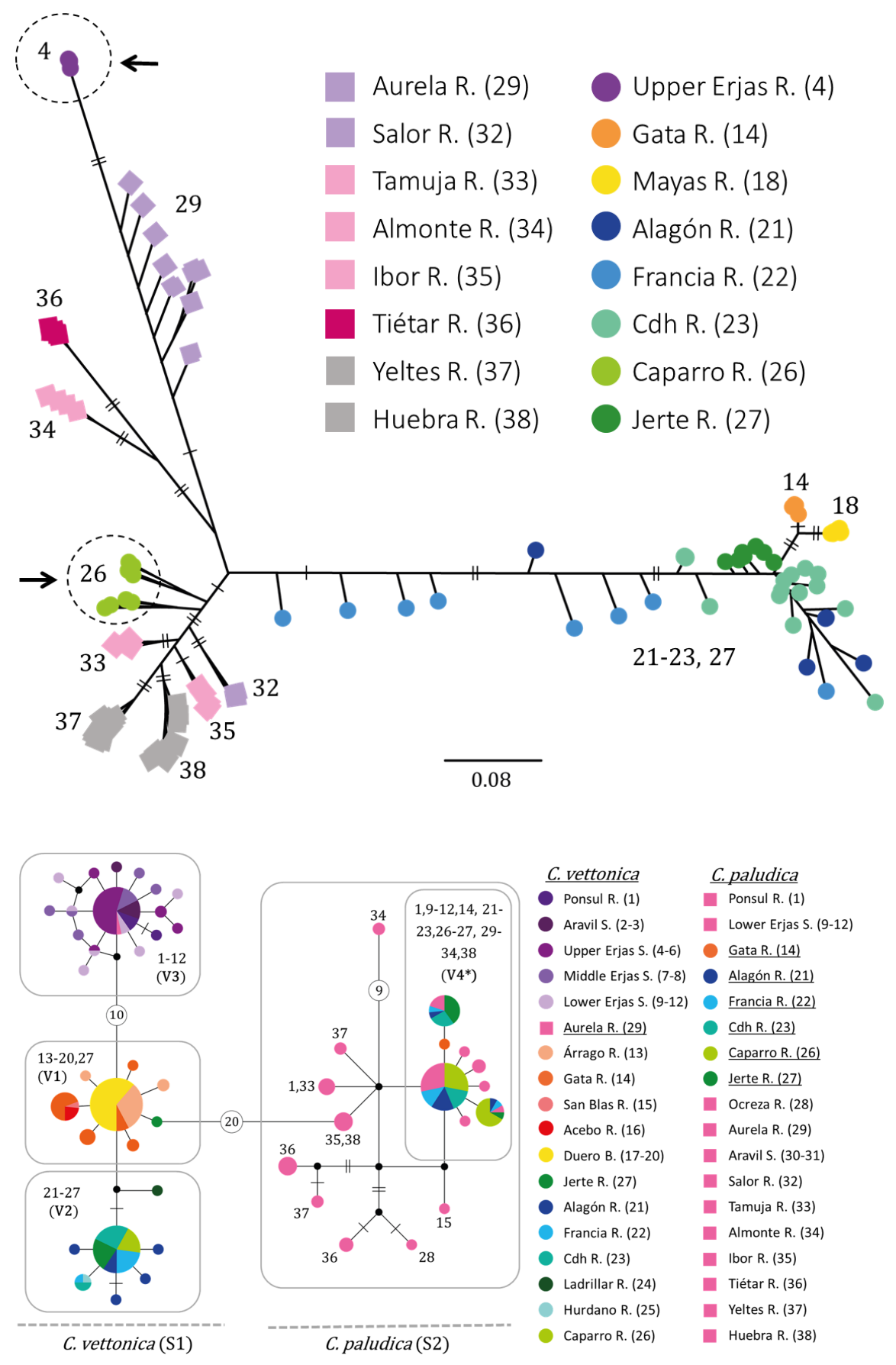

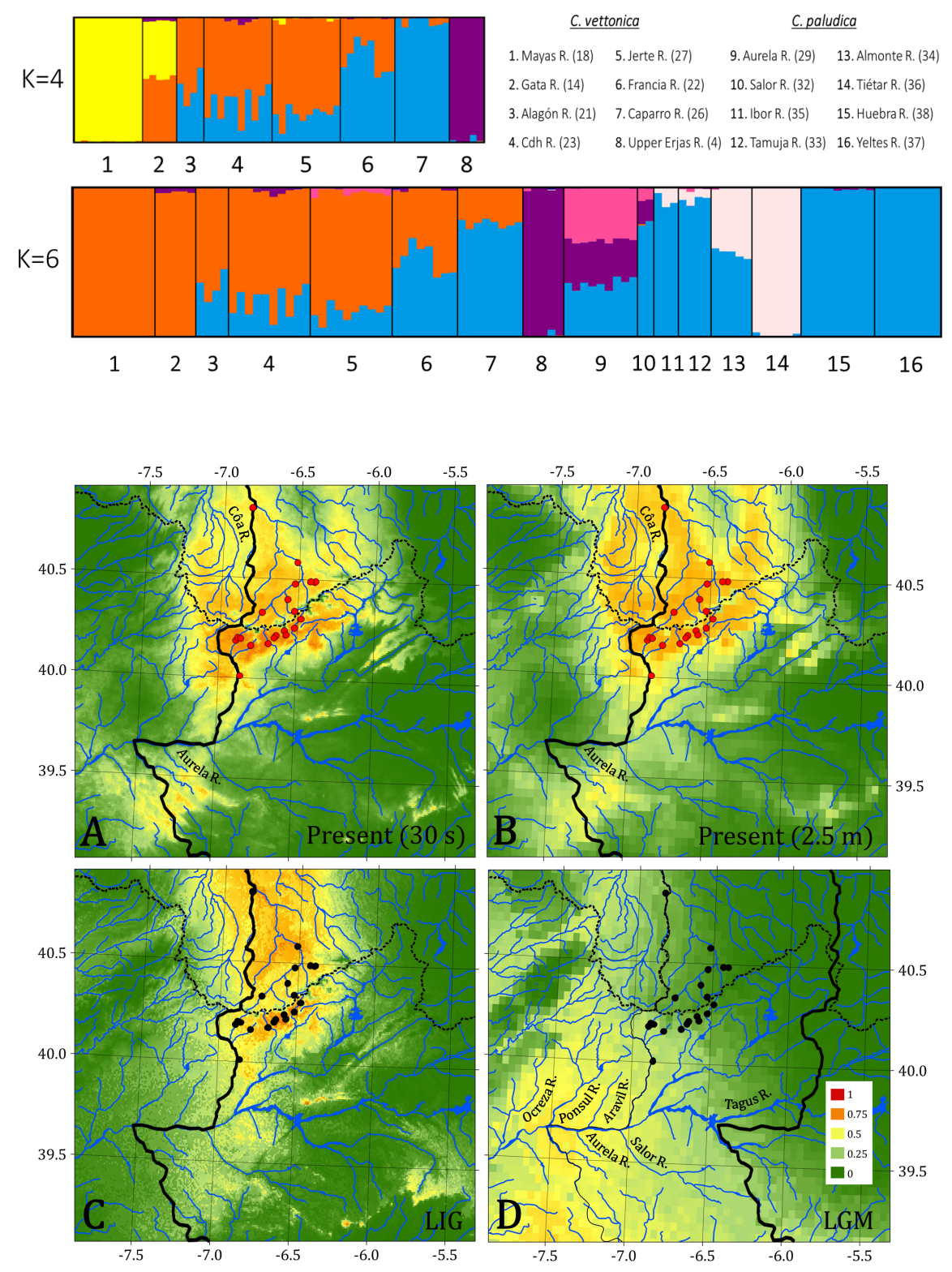


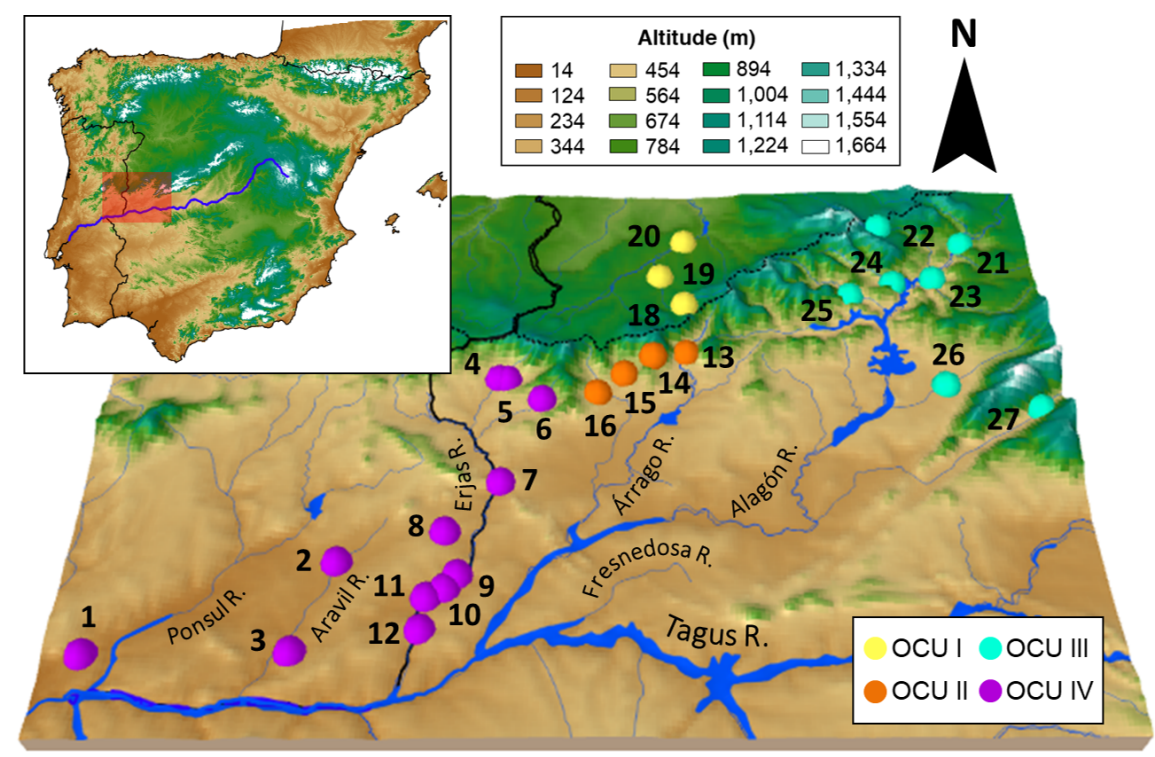

